\title{
Feeding Behavior of Podisus maculiventris (Say) (Hemiptera: Pentatomidae): Implications for Mass Rearing and Biological Control
}

\author{
Sudan Gyawaly \\ West Virginia University
}

Follow this and additional works at: https://researchrepository.wvu.edu/etd

\section{Recommended Citation}

Gyawaly, Sudan, "Feeding Behavior of Podisus maculiventris (Say) (Hemiptera: Pentatomidae): Implications for Mass Rearing and Biological Control" (2011). Graduate Theses, Dissertations, and Problem Reports. 4727.

https://researchrepository.wvu.edu/etd/4727

This Thesis is protected by copyright and/or related rights. It has been brought to you by the The Research Repository @ WVU with permission from the rights-holder(s). You are free to use this Thesis in any way that is permitted by the copyright and related rights legislation that applies to your use. For other uses you must obtain permission from the rights-holder(s) directly, unless additional rights are indicated by a Creative Commons license in the record and/ or on the work itself. This Thesis has been accepted for inclusion in WVU Graduate Theses, Dissertations, and Problem Reports collection by an authorized administrator of The Research Repository @ WVU. For more information, please contact researchrepository@mail.wvu.edu. 


\title{
Feeding Behavior of Podisus maculiventris (Say) (Hemiptera: Pentatomidae): Implications for Mass Rearing and Biological Control
}

\author{
Sudan Gyawaly \\ Thesis submitted to the Davis College of Agriculture, Natural Resources and \\ Design at West Virginia University \\ in partial fulfillment of the requirements for the degree of \\ Master of Science \\ in \\ Plant and Soil Sciences - Entomology \\ Yong-Lak Park, Ph.D., Chair \\ Rakesh Chandran, Ph.D. \\ Tracy C. Leskey, Ph.D. \\ Division of Plant and Soil Sciences \\ Morgantown, West Virginia \\ 2011
}

Keywords: integrated pest management, spined soldier bug, yellow mealworm, prey preference 


\section{ABSTRACT \\ Feeding Behavior of Podisus maculiventris (Say) (Hemiptera: Pentatomidae): Implications for Mass Rearing and Biological Control}

Sudan Gyawaly

Spined soldier bug, Podisus maculiventris (Say) (Hemiptera: Pentatomidae), is a generalist predator feeding on more than 70 different insect species. $P$. maculiventris is noted for its potential for augmentative release against coleopteran and lepidopteran larvae. Successful mass rearing and determination of potential prey of a biological control agent are crucial factors that need consideration for success of a biological control agent in augmentative biological control. Firstly, study was conducted to investigate feeding behavior of $P$. maculiventris using yellow mealworm, Tenebrio molitor (Coleoptera: Tenebrionidae). Using different life stages of $T$. molitor that $P$. maculiventris could potentially feed on in mass rearing system, feeding preferences of $P$. maculiventris were determined. $P$. maculiventris significantly preferred to feed on large larvae against small larvae of $T$. molitor. The different stages of $P$. maculiventris differed significantly in terms of daily hemolymph consumption: fifth instars consumed the highest amount per day. Body mass of the adult $P$. maculiventris was positively correlated with amount of hemolymph consumed per day. Secondly, study was carried out to investigate the feeding preference and feeding ability of $P$. maculiventris on different types of larvae. Using smooth, hairy and coleopteran larvae, the feeding preferences of $P$. maculiventris were determined. Third instars, fifth instars and adults of $P$. maculiventris significantly preferred to feed on smooth larvae. The hairy larvae were the least preferred. $P$. maculiventris showed the highest ability to feed on smooth larval species followed by coleopteran and hairy larvae. The findings of this thesis have important implications for successful biological control using $P$. maculiventris. 


\section{ACKNOWLEDGEMENTS}

I would like to sincerely thank the Davis College of Agriculture, Natural Resources and Design for offering me higher study opportunity and allowing me to be a part of their prestigious graduate program.

I would like to thank Dr. Yong-Lak Park, my major advisor and professor for his continuous support, guidance and direction so as to complete this project. His scientific input, ideas, patience have helped me to be a better graduate student. I would also like to thank my committee members Dr. Rakesh Chandran and Dr. Tracy Leskey for their thorough support, patience, scientific ideas and moreover their understanding of problems I faced during this project. I would not have been able to complete my graduate studies without their input.

I would like to thank Vicky Kondo, consultant for my thesis, for her help and support in the laboratory. Her role in maintaining a healthy working lab environment and help during mass rearing and collecting of the insects have helped this project to run smoother. She is an integral part of this project. Also, this acknowledgement page will not be complete without a special mention and thanks to my fellow graduate students, Matthew McKinney, Sunghoon Baek and Vimal Varghese. They have made my stay at West Virginia University a memorable and academically fruitful one.

I would like to thank my parents, Mr. Shashi Dhar Gyawaly and Mrs. Kamala Gyawaly, my family and friends for their continuous support, faith and belief in me and my abilities. Lastly, I would like to thank everyone who was associated with my project and has been helpful and friendly during my stay as a graduate student. 


\section{TABLE OF CONTENTS}

Chapter $1 \quad$ Introduction

Thesis Organization

General Introduction

Objective of Study

Literature Review

References Cited

Chapter 2 Feeding Preference and Feeding Potential of Podisus

maculiventris (Hemiptera: Pentatomidae) on Different Life

Stages of Tenebrio molitor (Coleoptera: Tenebrionidae)

Abstract

Materials and Methods

Results

Discussion

Acknowledgements

References Cited

Chapter 3 Feeding Preference and Feeding Behavior of Podisus

maculiventris on Smooth, Hairy and Coleopteran larvae

Abstract

Materials and Methods

Results

36

Discussion

38

Acknowledgements

39

References Cited

Conclusions 


\section{LIST OF TABLES}

Chapter 2 Feeding Preference and Feeding Potential of Podisus maculiventris (Hemiptera: Pentatomidae) on Different Life Stages

of Tenebrio molitor (Coleoptera: Tenebrionidae)

Table 1. Percentage feeding preference of $P$. maculiventris on different life stages of T. molitor

Table 2. Amount of hemolymph (mean \pm SEM) of $T$. molitor consumed by different stages of $P$. maculiventris per day and feeding equivalency when the feeding

Chapter 3 Feeding Preference and Feeding Behavior of Podisus maculiventris (Hemiptera: Pentatomidae) on Smooth, Hairy and Coleopteran Larvae

Table 1. Frequency of first attack of $P$. maculiventris on different types of larvae

Table 2. Feeding preference of $P$. maculiventris on different types of larvae 


\section{LIST OF FIGURES}

Chapter 1 Introduction

Figure 1. Morphology of P. maculiventris

Chapter 2 Feeding Preference and Feeding Potential of Podisus

maculiventris (Hemiptera: Pentatomidae) on Different Life

Stages of Tenebrio molitor (Coleoptera: Tenebrionidae)

Figure 1. An arena for testing preference of $P$. maculiventris

on different $T$. molitor stages in a quadrant Petri dish

Figure 2. Relationship between adult $P$. maculiventris body weight and amount of T. molitor hemolymph consumed

Chapter 3 Feeding Preference and Feeding Potential of Podisus maculiventris (Hemiptera: Pentatomidae) on Different Life Stages of Tenebrio molitor (Coleoptera: Tenebrionidae)

Figure 1. An arena for testing preference of $P$. maculiventris for different types of larvae

Figure 2. Mortality of different larval species for the third instar, fifth instar, and adult $P$. maculiventris feeding: $P$. rapae, $E$. rimosalis (smooth); $L$. decemlineata, $E$ varivestis (coleopteran); H. cunea (hairy)

Figure 3. Number of attacks prior to effective feeding by the third instars of $P$. maculiventris on different larvae: $P$. rapae, $E$. rimosalis (smooth); L. decemlineata, $E$ varivestis (coleopteran); H. cunea (hairy). Note that there was no effect of larva species on number of attack prior to effective feeding on different larvae for the fifth instar and adult $P$. maculiventris 


\section{CHAPTER 1: INTRODUCTION}

\section{Thesis Organization}

This thesis is organized into four chapters. Chapter 1 is a general introduction to this research and a literature review. Chapter 2 reports feeding preference of the spined soldier bug, Podisus maculiventris (Say) (Hemiptera: Pentatomidae), on different life stages of the yellow mealworm, Tenebrio molitor L. (Coleoptera: Tenebrionidae). Chapter 3 discusses the feeding preference of $P$. maculiventris on different types of larvae. Chapter 4 provides a general conclusion of this study. This thesis was prepared according to the publication guidelines established by the Entomological Society of America.

\section{General Introduction}

Pests such as insects, weeds and pathogens cause tremendous economic loss globally by damaging agriculture products in the field or in storage. The damage caused by insects and animal pests to crops stands second to damage caused by weed (Oerke 2006). Insecticides have long been major means for insect control and their use in pest management has increased over the years. Grube et al. (2011) estimated that a total of 404.6 million $\mathrm{kg}$ of insecticide with monetary value of ca. $\$ 11$ billion was applied globally in the year 2007. Although insecticides provide effective crop protection, they adversely affect human and animal health, pollute the environment and cause destruction of other non-target insects including beneficial insects (Newsom 1967). Many insect pests have developed resistance to insecticides (Luttrell et al 1984, Roditakis 2005) and thus have become more difficult to control. In this scenario, there is a need for sustainable and environment-friendly alternatives to insecticides. 
Biological control of insects, the use of predators, parasitoids, parasites or pathogens to control pest insects, has been considered one of the effective environment-friendly alternatives to insecticides. Biological control is one of the important components of integrated pest management. The emphasis on using biological control in pest management has resulted in exploration of biological control agents and more than 150 species of arthropods are available

commercially (Anonymous 2001). Introduced biological control agents such as vedalia beetle (Rodalia cardinalis) and many other species have been used with significant success in biological control. However, there is growing concern over the use of non-native biological control agents recently because of the possibility of their negative impact on non-target species and the environment (Howarth 1991, Koch and Galvan 2008). Therefore, the use of native natural enemies has been emphasized more recently. In this thesis, I report the feeding behavior of spined soldier bug, Podisus maculiventris, (Hemiptera: Pentatomidae) a native North American insect predator, to enhance and examine its usefulness as a biological control agent.

\section{Objectives of Study}

The goal of this research was to develop a protocol and method that would make mass rearing of $P$. maculiventris more efficient and facilitate bio-control using $P$. maculiventris. The objectives of the study were:

(1) to determine the most preferred life stage of $T$. molitor used as prey for $P$. maculiventris in a mass rearing system (Chapter 2) and

(2) to investigate the feeding preference of $P$. maculiventris to various larval types of major insect pests (Chapter 3). 


\section{Literature Review}

Life history of $\boldsymbol{P}$. maculiventris. $P$. maculiventris is a generalist predator and a facultative plant feeder which feeds upon insect prey from an early stage of its life (Mukerji and LeRoux 1965). P. maculiventris is native to North America with habitat ranging as far east as Vermont to California in the west and as far south as Florida to Quebec in the north (Froeschner 1998). P. maculiventris has been reported to feed on insects in $>40$ families and eight orders (Mukerji and LeRoux 1965, Warren and Wallis 1971, McPherson 1980). P. maculiventris occurs in several agroecosystems including agricultural lands, forest, and stream banks throughout summer (Evans 1982). In agricultural lands, P. maculiventris generally occurs in apple, soybean, cotton, alfalfa, potato, corn and celery (Stoner 1930, Wheeler 1977, MacLellan 1979, McPherson et al. 1982, Heimpel and Hough-Goldstein 1992, Bundy and McPherson 2000).

P. maculiventris undergoes incomplete metamorphosis with five nymphal instars before it reaches to adulthood. Under laboratory conditions, after 3-10 d of mating, a female $P$. maculiventris lays an average of 300 eggs in several masses (Mukerji and Lerux 1965) usually on the upper sides of leaves (Esselbaugh 1946). An egg mass generally consists of 30-40 eggs which hatch in 4-7 d. The first instar lasts 4-7 d, during which time nymphs only require moisture. The subsequent instars feed on insect prey and the amount of feeding increases with the increase in body size. Each of the second, third and fourth instars last for 4-8 d. The fifth instars become adults in 8-11 d. Adult $P$. maculiventris mate $2-4 \mathrm{~d}$ after emergence and longevities of males and females are ca. 180 and $125 \mathrm{~d}$, respectively.

In the field, $P$. maculiventris overwinters as an adult in ground debris or under the bark of deciduous trees or along their borders (Jones and Sullivan 1981, Herrick and Reitz 2004). In northern Florida, overwintered adults can be active as early as March and produce two 
generations per year (Herrick and Reitz 2004). However, in the laboratory P. maculiventris can have more than seven generation each year without exhibiting growth arrest or obligate diapauses (Mukerji and LeRux 1965).

Morphology of $\boldsymbol{P}$. maculiventris. The eggs of $P$. maculiventris are pale yellow to metallic blue and oval (0.88-1.08 $\mathrm{mm}$ in length and $0.78-1.00 \mathrm{~mm}$ in diameter) with long spines densely clustered on an operculum (Bundy and McPherson 2000) (Fig. 1 A). The first and the second instars are reddish, broadly oval to almost circular: $1.15-1.60-\mathrm{mm}$ long and $0.90-1.35$ $\mathrm{mm}$ wide for the first instars (Decoursey and Esselbaugh 1962) and 1.75-2.95 mm long and 1.40-2.05 mm wide for the second instars. The second instars can be distinguished from first instars by relatively larger size and pale colored antennae; the color of antennae is black for the first instar (Fig. 1B and C). The third instars have orange to whitish abdominal terga, and their body is oval (2.6-4.3 mm long and 1.8-3.1 mm wide) (Fig. $1 \mathrm{D})$. The fourth instars look similar to third instars except they are larger (3.4-5.8 $\mathrm{mm}$ long and $2.7-4.0 \mathrm{~mm}$ wide) with angular spots on pronotum and mesonotum (Fig. 1 E). The sizes of the fifth instars vary $(5.9-8.6 \mathrm{~mm}$ in length and 4.4-5.6 $\mathrm{mm}$ in width) and these nymphs have well developed wing pads (Fig. $1 \mathrm{~F}$ ). The adult P. maculiventris is $8.5-13.0 \mathrm{~mm}$ long and can be distinguished from other stinkbugs by prominent spines on the shoulders and a well-developed ventral abdominal spine which projects between the hind coxae (McPherson 1982) (Fig. 1 G). Similarly, the female P. maculiventris can be distinguished from males by their relatively larger size and by the presence of a slit in their genitalia (Fig. $1 \mathrm{H})$.

Pest management with $P$. maculiventris. $P$. maculiventris has been reported as a key natural enemy of fall webworm, Hyphantria cunea; pine sawfly, Neodiprion spp.; eastern tent caterpillar, Malacosoma americanum; elm leaf beetle, Pyrrhalta luteola and Colorado potato 
beetle, Leptinotarsa decemlineata under natural conditions (Mukerji and LeRoux 1965, Warren and Wallis 1971, McPherson 1980). P. maculiventris is a noticeable predator of pests of soybean and other field crops (Waddill and Shepard 1975). P. maculiventris is considered a potential alternative to pesticides to control Colorado potato beetle (Stamopoulos and Chloridis 1994, Hough-Goldstein and McPherson 1996).

Although few studies have been conducted to test the efficacy of $P$. maculiventris for biological control in a field situation, studies have reported that $P$. maculiventris could potentially control diverse species of pests. Desurmont and Weston (2008) showed that $P$. maculiventris could successfully reduce the impact of viburnum leaf beetles, Pyrrhalta viburni and De Clercq and Degheelee (1994) found very high predation rate of $P$. maculiventris on beet armyworm larvae, Spodoptera exigua. De Clercq et al. (2002) also reported very high predation rate of $P$. maculiventris on different life stages (eggs, nymphs and adults) of southern green stink bugs, Nezara viridula under the laboratory condition. From field cage studies, Lopez et al. (1976) reported that $P$. maculiventris third instar and adults were among the most efficient predators in controlling third instar larvae of cotton bollworm, Heliothis zea. They also reported that release of $P$. maculiventris at the rate of 100,000/acre could substantially reduce the number of tobacco budworm, Heliothis virescens larvae. Another field cage study has also shown very high potential of $P$. maculiventris fifth instars and adults for the control of larvae of cabbage large white butterfly, Pieris brassicae (Stamopoulos and Chloridis 1994). P. maculiventris has been reported to reduce the defoliation of cotton plants by consuming more than $75 \%$ of the cutworm, Peridroma saucia larvae within $48 \mathrm{hr}$ of release (Ables and McCommas 1982) in greenhouse cotton. Furthermore, the aggregation pheromone of $P$. maculiventris that attract both 
nymphs and adults have been identified and used to enhance the efficacy of $P$. maculiventris in suppressing Colorado potato beetles (Aldrich and Cantelo 1999).

Mass rearing of $\boldsymbol{P}$. maculiventris. $P$. maculiventris has been studied over the last 50 years with regard to successful mass rearing because of its potential in augmentative biological control. Mukerji and LeRux (1965) studied the biology of P. maculiventris in the laboratory and reported that it can develop successfully and reproduce when fed Galleria mellonella (Lepidoptera: Pyralidae) larvae. Coudron et al. (2007) used fourth instars larvae of Trichoplusia $n i$ (Lepidoptera: Noctuidae) for rearing P. maculiventris. De Clercq et al. (1998) compared unnatural prey species such as T. molitor (Coleoptera: Tenebrionidae) and artificial diets with the G. mellonella. They found that T. molitor was comparable to G. mellonella for mass rearing of $P$. maculiventris while bovine liver based artificial diet was not preferred. Although few studies have described the mass rearing methods of $P$. maculiventris, studies showed that $G$. mellonella larvae, T. molitor larvae or pupae, or some coleopteran and lepidopteran larvae or pupae with provision of additional moisture source could be used for mass rearing.

Feeding preference test. Feeding preference tests of arthropod predators are generally studied in in the field cages or in the laboratories. In field cage studies, prey are offered on a plant and the preference of the predator for a prey are determined (Bearnays 1989). Feeding preference of natural enemies has been widely studied in the laboratory using Petri dishes or other containers to determine preference for a particular type of prey (Eubanks and Denno 2000, Cogni et al. 2002, Legaspi and Legaspi 2004). A general procedure for conducting feeding preference tests for an arthropod species involves offering equal number of prey species in a confined arena, exposing the natural enemy to prey for generally $24 \mathrm{hr}$, and recording the number of prey species consumed by natural enemies. Data in feeding preference tests can be 
analyzed in various ways. In general, data are analyzed by using either ANOVA if multiple individuals of each of the choices are used (Eubanks and Denno 2000, Legaspi and Legaspi 2004) or chi-square tests if single individual of each of the choices is used for the preference test (Cogni et al. 2002).

\section{References Cited}

Ables, J. R., and D. W. McCommas, Jr. 1982. Efficacy of Podisus maculiventris as a predator of variegated cutworm on greenhouse cotton. J. Ga. Entomol. Soc. 17: 204-206.

Aldrich, J. R., and W. W. Cantelo. 1999. Suppression of Colorado potato beetle infestation by pheromone mediated augmentation of the predatory spined soldier bug, Podisus maculiventris (Say) (Heteroptera: Pentatomidae). Agric. For. Entomol. 1: 209-217.

Anonymous. 2001. 2002 Directory of least-toxic pest control products. IPM Pract. 23: 1-39.

Bernays, E. A. 1989. Host range in phytophagous insects: the potential role of generalist predators. Evol. Ecol. 3: 299-311.

Bundy, C. S., and R. M. McPherson. 2000. Morphological examination of stink bug (Heteroptera: Pentatomidae) eggs on cotton and soybeans, with a key to genera. Ann. Entomol. Soc. Am. 93: 616-624.

Cogni, R., A. V. L. Freitas, and F. Amaral Filho. 2002. Influence of prey size on predation success by Zelus longipes L. (Het., Reduviidae). J. Appl. Entomol. 126: 74-78.

Coudron, T. A., M. R. Ellersieck, and K. S. Shelby. 2007. Influence of diet on long-term cold storage of the predator Podisus maculiventris (Say) (Heteroptera: Pentatomidae). Biol. Contr. 42: 186-195.

De Clercq, P., and D. Degheele. 1994. Laboratory measurement of predation by Podisus maculiventris and P. sagitta (Hemiptera: Pentatomidae) on beet armyworm 
(Lepidoptera: Noctuidae). J. Econ. Entomol. 87: 76-83.

De Clercq, P., F. Merleved, and L. Tirry. 1998. Unnatural prey and artificial diets for rearing Podisus maculiventris (Heteroptera: Pentatomidae). Biol. Contr. 12: 137-142.

De Clercq, P., K. Wyckhuys, H. N. De Olivera, and J. Klapwijk. 2002. Predation by Podisus maculiventris on different life stages of Nezara viridula. Fla. Entomol. 85: 197-202.

Decoursey, R. M., and C. O. Esselbaugh. 1962. Descriptions of the nymphal stages of some North American Pentatomidae (Hemipera-Heteroptera). Ann. Entomol. Soc. Am. 55: $323-342$.

Desurmont, G., and P.A. Weston. 2008. Predation by Podisus maculiventris (Say) (Hemiptera: Pentatomidae) on viburnum leaf beetle, Pyrrhalta viburni (Paykull) (Coleoptera: Chrysomelidae), under laboratory and field conditions. Environ. Entomol. 37: 12411251.

Esselbaugh, C. O. 1946. A study of the eggs of the Pentatomidae (Hemiptera). Ann. Entomol. Soc. Am. 39: 667-691.

Eubanks, M. D., and R. F. Denno. 2000. Health food versus fast food: the effects of prey quality and mobility on prey selection by a generalist predator and indirect interactions among prey species. Ecol. Entomol. 25: 140-146.

Evans, E.W. 1982. Consequences of body size for fecundity in the predatory stinkbug, Podisus maculiventris (Hemiptera: Pentatomidae). Ann. Entomol. Soc. Am. 75: 418-420.

Froeschener, R. C. 1998. Family Pentatomidae pp. 544-597. In T. J. Henry and R. C. Froeschner (eds.), Catalog of the Heteroptera or true bugs of Canada and the continental United States. CRC press LLC, Boca Raton, FL. 
Grube, A., D. Donaldson, T. Kiely, and L. Wu. 2011. Pesticide industry sales and usage 2006 and 2007 market estimates. http://www.epa.gov/opp00001/pestsales/07pestsales/market_estimates2007.pdf.

Heimpel, G. E., and J. A. Hough-Goldstein. 1992. A survey of arthropod predators of Leptinotarsa decemlineata (Say) in Delaware potato fields. J. Agric. Entomol. 9: 37142.

Herrick, N. J., and S. R. Reitz. 2004. Temporal occurrence of Podisus maculiventris (Hemiptera: Heteroptera: Pentatomidae) in North Florida. Fla. Entomol. 87: 587-590.

Hough-Goldstein, J. A., and D. McPherson. 1996. Comparison of Perillus bioculatus and Podisus maculiventris (Hemiptera: Pentatomidae) as potential control agents of the Colorado potato beetle (Coleoptera: Chrysomelidae). J. Econ. Entomol. 89: 1116-1123.

Howarth, F. G. 1991. Environmental impacts of classical biological control. Annu. Rev. Entomol. 36: 485-509.

Jones, W. A., and M. J. Sullivan. 1981. Overwintering habitats, spring emergence patterns, and winter mortality of some South Carolina Hemiptera. Environ. Entomol. 10: 409-414.

Koch, R. L., and T. L. Galvan. 2008. Bad side of a good beetle: the North American experience with Harmonia axyridis. Biocontrol 53: 23-35.

Legaspi, J. C., and B. C. Legaspi, Jr. 2004. Does a polyphagous predator prefer prey species that confer reproductive advantage? : case study of Podisus maculiventris. Environ. Entomol. 33: 1401-1409.

Lopez, J. D., R. L. Ridgway, and R. E. Pinnell. 1976. Comparative efficacy of four insect predators of the bollworm and tobacco budworm. Environ. Entomol. 5: 1160-1164. 
Luttrell, R. G., R. T. Roush, A. Ali, J. S. Mink, M. R. Reid, and G. L. Snodgrass. 1987. Pyrethroid resistance in field populations of $H$. virescens (Lepidoptera: Noctuidae) in Mississippi in 1986. J. Econ. Entomol. 80: 985-989.

MacLellan, C. R. 1979. Pest damage and insect fauna of Nova Scotia apple orchards: 19531977. Can. Entomol. 111: 985-1004.

McPherson, J. E. 1980. A list of the prey species of Podisus maculiventris (Hemiptera: Pentatomidae). Great Lakes Entomol. 13: 18-24.

McPherson, J.E. 1982. The Pentatomoidea (Hemiptera) of northeastern North America with emphasis on the fauna of Illinois. Southern Illinois University Press, Carbondale, IL.

McPherson, R. M., J. C. Smith, and W. A. Allen. 1982. Incidence of arthropod predators in different soybean cropping systems. Environ. Entomol. 11: 685-689.

Mukerji, M. K., and E. J. LeRoux. 1965. Laboratory rearing of a Quebec strain of the pentatomid predator, Podisus maculiventris (Say) (Hemiptera: Pentatomidae). Phytoprotection 46: 40-60.

Newsom, L. D. 1967. Consequences of insecticide use on non-target organisms. Annu. Rev. Entomol. 12: 257-286.

Oerke, E.C. 2006. Crop losses to pests. J. Agric. Sci. 144: 31-43.

Roditakis, E., N. E. Roditakis, and A. Tsagkarakou. 2005. Insecticide resistance in Bemisia tabaci (Homoptera: Aleyrodidae) populations from Crete. Pest Man. Sci. 61: 577-582.

Stamopoulos, D. C., and A. Chloridis. 1994. Predation rates, survivorship and development of Podisus maculiventris (Het.: Pentatomidae) on larvae of Leptinotarsa decemlineata (Col.: Chrysomelidae) and Pieris Brassicae (Lep.: Pieridae), under field conditions. Entomophaga 39: 13-9. 
Stoner D., 1930. Spined soldier bug reared on celery leaf-tyer. Fla. Entomol. 14: 21-22.

Waddill, V., and M. Shephard. 1975. Dispersal of Podisus maculiventris nymphs in soybeans. Environ. Entomol. 4: 233-234.

Warren, L. O., and G. Wallis. 1971. Biology of the spined soldier bug, Podisus maculiventris (Hemiptera: Pentatomidae). J. Ga. Entomol. Soc. 6: 109-116.

Wheeler, A. G. 1977. Studies on the arthropod fauna of alfalfa VII. Predaceous insects. Can. Entomol. 109: 423-427. 

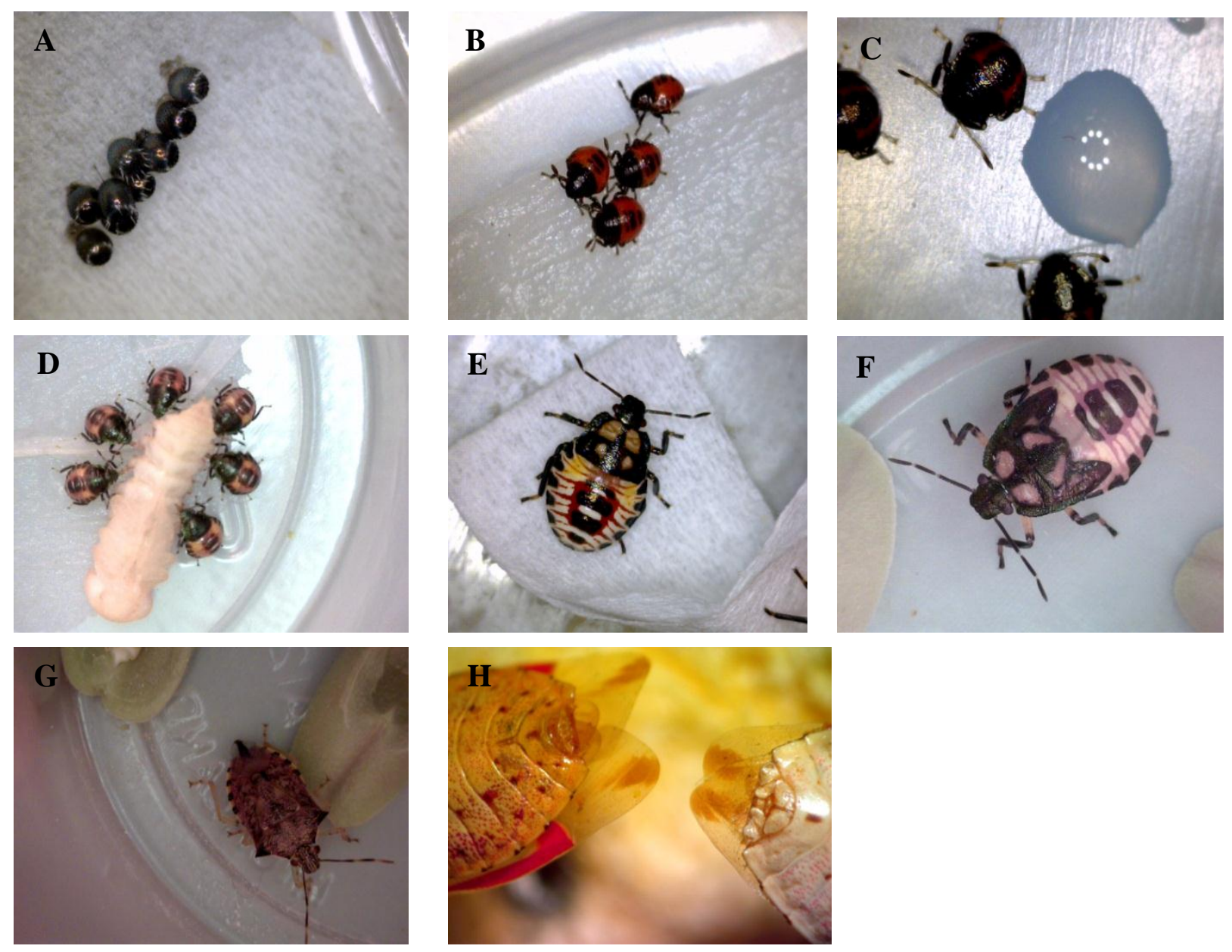

Fig. 1. Morphology of P. maculiventris eggs (A), first instars (B), second instars (C), third instars (D), fourth instar (E), fifth instar (F), and adult (G). Reproductive organs (H) of adult male (left) and female (right). (Photos were provided by P. Joyce and Y. L. Park at West Virginia University). 


\title{
CHAPTER 2: Feeding Preference and Feeding Potential of Podisus maculiventris (Hemiptera: Pentatomidae) on Different Life Stages of Tenebrio molitor (Coleoptera: Tenebrionidae)
}

\begin{abstract}
The spined soldier bug, Podisus maculiventris (Say) (Hemiptera: Pentatomidae), is a generalist predator feeding on more than 70 insect pest species. Although the value of $P$. maculiventris as a biological control agent has been proven, no sustainable mass rearing systems have been developed. A series of experiments were carried out to test the feeding preference of P. maculiventris on various life stages of yellow mealworm, Tenebrio molitor (Coleoptera: Tenebrionidae), and to quantify the amount of hemolymph consumed by $P$. maculiventris. Preference test showed that $P$. maculiventris adults significantly preferred to feed on large larvae $\left(\chi^{2}=11.75 ;\right.$ d.f. $\left.=3 ; P=0.0083\right)$. Amount of hemolymph consumed during feeding differed significantly $(F=38.48$; d.f. $=5,44 ; P<0.001)$ among stages of $P$. maculiventris; the largest amount of hemolymph was consumed by the fifth instar that could feed on $0.035 \pm 0.011 \mathrm{~g}$ of hemolymph of T. molitor per day. Regression analysis showed that the feeding amount of $P$. maculiventris adults was positively correlated with their body weight $(F=8.49$; d.f. $=1,26 ; P=$ 0.0072). The practical applications of these results related to the development of a $P$. maculiventris mass rearing system are discussed.
\end{abstract}

Keywords: spined soldier bug, unnatural prey, mass rearing, feeding equivalent 
Augmentative biological control refers to techniques used to increase the numbers of natural enemies to control pests. Augmentative biological control can be as effective as chemical control and is considered an alternative to chemical control (Parella et al. 1992, Obrycki et al. 1997, Van Lenteren 2006). For example, Parella et al. (1992) reported that the augmentative releases of parasitoid Diglyphus begini (Hymenoptera: Eulophidae) to control chrysanthemum leaf miner, Liriomyza trifolii in green house in California was cheaper compared to chemical control. There are two methods of augmentative biological control: inundatative or inoculative release (Pedigo 2002). Inundative releases seek immediate control of pests by released individuals of natural enemies while inoculative release aims to control the pests in successive generations of the natural enemies (Eilenberg et al. 2001). Supplementary releases of natural enemies are essential for both inundative and inoculative methods. Moreover, periodic release of large numbers of natural enemies is essential for inundative biological control. However, mass rearing techniques for most of the natural enemies are expensive and economic mass rearing of natural enemies is required for their use in augmentative biological control specifically in inundative biological control.

Natural enemies in biological control are generally reared on live natural preys. However, their mass rearing on the natural prey can be very expensive and thus efforts have been made to develop economical mass rearing of natural enemies using artificial diets. Though previous studies reported promising artificial diets for mass rearing of neuropteran (Cohen and Smith 1998) and coleopteran (Reeve et al. 2003) natural enemies, the survival and fecundity of other natural enemies such as hemipterans reared on artificial diet were lower (De Clercq and Degheele 1992, Coudron et al. 2002, Silva et al. 2009). Riddick (2009) concluded that artificial diets developed for most of the predators are inadequate for continuous mass rearing. Therefore, 
efforts are being made to make mass rearing cost effective by rearing natural enemies on unnatural prey. Unnatural prey, though, are not available in the natural habitats of the natural enemies; many generalist natural enemies are able to feed on, survive and reproduce when reared on unnatural prey. The production of some unnatural prey is cheap and are being used for the mass rearing of many natural enemies. Some natural enemies were successfully mass reared with unnatural prey (Ridgeway et al. 1970, Grundy et al. 2000, Riddick 2009). Lacerda et al. (2004) reported that the asopine bug, Podisus distinctus (Hemiptera: Pentatomidae), could be reared successfully on three unnatural prey species: Bombyx mori (Lepidoptera: Bombycidae), Musca domestica (Diptera: Muscidae) and Tenebrio molitor (Coleoptera: Tenebrionidae).

Podisus maculiventris (Say) (Hemiptera: Pentatomidae) is a polyphagous predator feeding on insects of more than 40 families in eight orders (McPherson 1980). P. maculiventris is reported to be an important predator in forest, fruits orchards and field crops (Warren and Wallis 1971, McPherson 1980). P. maculiventris has high potential as an augmentative biological control agent against Colorado potato beetles and other lepidopteran larvae because of higher reproductive rates of $P$. maculiventris in laboratory (Biever and Chauvin 1992, HoughGoldstein and McPherson 1996). Various studies have been carried out regarding the potential of mass rearing of $P$. maculiventris on natural prey. Marston et al. (1978) reported that $P$. maculiventris could be reared on noctuid larvae. However, rearing P. maculiventris on natural prey is expensive and not cost effective. Studies have reported the potentiality of $P$. maculiventris to be reared on unnatural prey species. Mukerji and LeRux (1965) reported that $P$. maculiventris could be reared in the laboratory on Galleria mellonella (Lepidoptera: Pyralidae). DeClerq et al. (1998) reported that T. molitor could be a suitable unnatural prey for the mass rearing of $P$. maculiventris because of less expenses required in the production of T. molitor. T. 
molitor is a stored grain pest which can be cheaply and easily mass produced and is also available in commercial insectaries. However, no study reports the feeding preference of $P$. maculiventris on different life stages of T. molitor. The determination of feeding preference of $P$. maculiventris is required to decide the life stage of $T$. molitor that can be used as prey in the mass rearing of $P$. maculiventris.

The amount of optimum prey needed for mass rearing of an insect is important because of higher mortality due to cannibalism when less prey is offered (Pires et al. 2011) and waste of expensive prey when excessive prey are offered. Wiedenmann and O'Neil (1990) showed that the survival and fecundity of $P$. maculiventris was highly reduced if less food is offered, indicating that provision of optimum amount of prey could reduce the cost of mass rearing. In addition, adequate prey quantity is essential for an insect for optimal fitness and for maximum reproductive potential (Omkar et al. 2010). Although $P$. maculiventris has high potential as a biological control agent, no well-defined mass rearing systems have been developed because of lack of information regarding mass rearing.

We carried out this study to investigate feeding preference of $P$. maculiventris on an unnatural prey (i.e. T. molitor 2 to develop a guideline for feeding $P$. maculiventris in mass rearing. The objectives of this study were to determine the feeding preference of $P$. maculiventris on different life stages of the T. molitor and to quantify the amount of T. molitor hemolymph consumed by $P$. maculiventris.

\section{Materials and Methods}

Experimental insects. $P$. maculiventris used in this study were obtained from rearing colonies maintained in the entomology laboratory at West Virginia University (Morgantown, 
WV) since June 2009. P. maculiventris was reared on T. molitor purchased from New York Worms (Long Island, NY).

Feeding preference of $\boldsymbol{P}$. maculiventris on various $\boldsymbol{T}$. molitor stages. Feeding preference test was carried out at a constant temperature $\left(23 \pm 2.3^{\circ} \mathrm{C}\right)$ and relative humidity $(65 \pm$ $3 \%)$ in the laboratory. A small larva $(1.0-1.5 \mathrm{~cm}$ in length), large larva $(2.5-3.0 \mathrm{~cm}$ in length), pupa and adult $T$. molitor were randomly assigned to a quadrant Petri dish (9-cm diameter) (Pyrex Petri Dishes, Science Kit and Boreal Laboratories, Tonawanda, NY) (Fig. 1). Then, one P. maculiventris (third instar, fifth instar, or adult) was introduced and released in the middle of the Petri dish and its first choice to a T. molitor stage was observed and recorded for $1 \mathrm{hr}$. Choice is defined as P. maculiventris successfully attacking and feeding upon T. molitor for $>1$ min. All P. maculiventris used in this study were starved for $18 \mathrm{hr}$. before the tests began. The preference test was repeated 36 times (no insect was used $>1$ time) for each of the third instar, the fifth instar, and adult $P$. maculiventris. Statistical significance of preference of $P$. maculiventris on T. molitor stages was determined using chi-square test (PROC PREQ, SAS Institute 2008).

Feeding equivalency of different stages of $\boldsymbol{P}$. maculiventris. An experiment was conducted to quantify the amount of T. molitor hemolymph consumed by $P$. maculiventris. More than 150 predacious $P$. maculiventris (i.e. except egg and the first instar) were separated from the rearing colony within 1-3 d after molting. The weight of $T$. molitor pupae were measured using an electronic balance (PB 303-S/Fact, Mettler-Toledo Inc., Columbus, $\mathrm{OH}$ ). Then, one $P$. maculiventris of each stage was exposed to the T. molitor pupa in a plastic cup (4-cm diameter) (Solo, Solo Cup Company, Urbana, IL). After $24 \mathrm{hr}$, weight of the T. molitor pupa was measured again to determine the amount of hemolymph consumed by $P$. maculiventris. Before the 
experiment, all P. maculiventris were starved for $24 \mathrm{hr}$ allowing access to water only. This experiment was repeated 30 times for each of the $P$. maculiventris stages (no insect was used $>1$ time). Because feeding amount by the younger instars was too small to measure, we combined and measured the weight loss of three $T$. molitor pupae together (i.e. ten replications per $P$. maculiventris stage). A total of 10 replications of pupae were used as controls (pupa without predators) with each instar. The difference in weight loss for pupae due to $P$. maculiventris feeding and control pupae were compared using paired t-test (PROC TTEST, SAS Institute 2008).

To compare feeding potential of different stages of $P$. maculiventris, we adopted the concept of injury equivalency proposed by Hutchins et al. (1988). They used the term injury equivalency to quantify overall amount of plant injury caused by multiple pest species with different feeding potential. In our study, feeding equivalency coefficient was calculated by setting the amount of hemolymph consumption by the second instar as 1.0. Feeding equivalency coefficients were calculated and data on hemolymph loss of T. molitor was analyzed with ANOVA and difference in means due to feeding for the second, third, fourth, fifth and adult ( male and female) were compared with Tukey's HSD test at 5\% error rate (PROC GLM, SAS Institute 2008).

\section{Relationship between body weights of adult $P$. maculiventris and feeding amount. An}

experiment was conducted to determine the relationship between body weights of adult $P$. maculiventris and the amount of T. molitor hemolymph consumed. More than $30 P$. maculiventris adults were randomly selected from the rearing colony. The weight of T. molitor pupae and an adult $P$. maculiventris were measured using an electronic balance (PB 303-S/Fact, Mettler-Toledo Inc., Columbus, OH). One T. molitor pupa was provided as prey for each $P$. 
maculiventris in a 9-cm-diameter Petri dish (Pyrex Petri Dishes, Science Kit and Boreal Laboratories, Tonawanda, NY). After $24 \mathrm{hr}$, the weight of the T. molitor pupa was measured again to determine the amount of hemolymph consumed by $P$. maculiventris. This experiment was repeated 28 times. The relationship between adult $P$. maculiventris weight and amount of $T$. molitor hemolymph loss was determined using regression analysis (PROC REG, SAS Institute 2008).

\section{Results}

Feeding preference of $\boldsymbol{P}$. maculiventris. The third instar, fifth instar and adult $P$. maculiventris preferred large larvae of T. molitor (Table 1). However, the feeding choice test was significant only for the adult stages of $P$. maculiventris $\left(\chi^{2}=11.75 ;\right.$ d.f. $\left.=3 ; P=0.008\right)$. The pair-wise comparison revealed a significant preference by adult $P$. maculiventris for large larvae over small larvae $\left(\chi^{2}=4.54\right.$; d.f. $\left.=1 ; P=0.033\right)$ or adults $\left(\chi^{2}=8.89\right.$; d.f. $\left.=1 ; P=0.003\right)$. However, there was no significant $(P>0.05)$ difference in preference of adult $P$. maculiventris between large larvae and pupae of T. molitor (Table 1).

Feeding equivalency of $\boldsymbol{P}$. maculiventris. The weight loss of $T$. molitor pupae by $P$. maculiventris feeding was significantly higher than that of controls $(t=6.74-11.80 ;$ d.f. $=18 ; P<$ 0.05). Also, there was significant difference in the amount of hemolymph consumption among different stages of $P$. maculiventris $(F=38.48$; d.f. $=5,44 ; P<0.001)$. The fifth instar $P$. maculiventris consumed the largest amount of hemolymph from T. molitor pupae and the smallest amount was consumed by the second instar (Table 2). When feeding equivalency for the second instar of $P$. maculiventris was designated as 1.0., feeding equivalencies were 1.83-9.45 and 6.21-5.67 for nymphs and adults, respectively (Table 2). 


\section{Effect of body weight of $\boldsymbol{P}$. maculiventris on the amount of hemolymph consumption.}

One adult $P$. maculiventris could consume $0.014 \pm 0.0108 \mathrm{~g}$ of $T$. molitor hemolymph per day. The body weight of adult $P$. maculiventris was positively correlated with the amount of $T$. molitor hemolymph consumed by $P$. maculiventris adults $($ d.f. $=1,26 ; F=8.49 ; P=0.0072)$ (Fig. 2).

\section{Discussion}

Previous studies showed that unnatural prey could be used for rearing natural enemies (Grundy et al. 2000, Riddick 2009). Production of natural enemies on many unnatural prey is economical because of easier and cheaper production techniques of natural enemies on unnatural prey (DeClercq et al. 1998, Uddin et al. 2005). Previous studies reported that many predatory hemipterans could be successfully reared on unnatural prey such as T. molitor (Grundy et. al. 2000, Lecerda et al. 2004). Grundy et al. (2000), for example, showed that Pristhesancus plagipennis (Hemiptera: Reduviidae) reared on dead T. molitor larvae had higher survivorship, increased body weight and faster development. DeClercq et al. (1998) reported that T. molitor could be a good unnatural prey for mass rearing of $P$. maculiventris.

Our study showed that, even though there was no significant difference, $P$. maculiventris showed preference to large T. molitor larvae. We observed that, among the four different life stages of $T$. molitor, large larvae were the most actively moving around and encountered $P$. maculiventris frequently. Such movement of large larvae might have evoked $P$. maculiventris to respond and attack large larvae. Even though small larvae of T. molitor also showed active movement, fewer attempts by $P$. maculiventris to attack small larvae were made. This indicates that $P$. maculiventris did not prefer to feed on very small prey when different choices are available. The less preference of $P$. maculiventris to $T$. molitor adults might be due to the very 
hard exoskeleton. Desurmont and Weston (2008) noted that P. maculiventris fed less on other coleopteran adults because of longer handling time most likely due to their hard body wall. Relatively higher preference of $P$. maculiventris to $T$. molitor pupae might be due to the lack of defense by the pupae.

The size of the different stages of $P$. maculiventris increased with their age: $1.60,2.95$, 4.3, 5.8, 8.6, $10.0 \mathrm{~mm}$ in length for the first, second, third, fourth, fifth instars and adult, respectively (Decoursey and Esselbaugh 1962, McPherson 1982). Our study showed that the amount of T. molitor hemolymph consumed each day increased with $P$. maculiventris stages except for the fifth instar; the fifth instar consumed the largest amount of hemolymph per day. Our study also showed that amount of hemolymph consumed also increased with the increase in the weight of $P$. maculiventris. We attribute the higher amount of hemolymph consumption by the fifth instars to physiological requirement that the fifth instars need more energy for imminent morphological and physiological development of reproductive organs. Strohmeyer et al. (1998) found that $P$. maculiventris females fed more than males, which is contradictory to our study. DeClercq and Degheele (1997) also reported that mated $P$. maculiventris female consumed more prey than males. We think that this contradiction was due to mating status of the $P$. maculiventris females. $P$. maculiventris adults we used in this study were virgin.

The results of this study imply two important considerations on mass rearing of $P$. maculiventris. First, the life stages of T. molitor should be taken into account for mass rearing of P. maculiventris. Because $P$. maculiventris preferred to feed on active large prey, providing live large T. molitor larvae may have physiological and developmental advantages for $P$. maculiventris. In contrast, providing small larvae might result in cannibalism because $P$. maculiventris less prefers to feed upon them. Second, the effects of life stages of the $P$. 
maculiventris on their feeding amounts need to be considered in mass rearing of $P$.

maculiventris. This study showed that larger amounts of hemolymph were consumed by the fifth instar and adult $P$. maculiventris, indicating that the age and size of $P$. maculiventris could be an important factor for determining the amount of prey needed in the mass rearing systems. Hemolymph consumption of one fifth instar P. maculiventris is equivalent to ca. ten second instars or ca. five third instars. Our observation indicates that one T. molitor pupa was enough for one fifth instar P. maculiventris for one day, which would be enough for the third instar for five days. Because the feeding potential of different life stages of $P$. maculiventris could vary significantly, the feeding equivalency will also help to decide the amount of $T$. molitor that each stages of the $P$. maculiventris need each day. The second, third, fourth and fifth instars $P$. maculiventris on average last for 5.5, 5, 5 and $9.5 \mathrm{~d}$ respectively (Mukerji and LeRux 1965). Our study indicates that the mass rearing of one $P$. maculiventris from second through fifth instar will require ca. 14 T. molitor.

\section{Acknowledgements}

We thank Vicki Kondo and Vimal Varghese for rearing insects and helping experiments. We also thank Matthew McKinney and Sunghoon Baek for their valuable suggestions to this study. The project was supported by State Horticultural Association of Pennsylvania and Hatch Project at West Virginia University.

\section{References Cited}

Biever, K. D., and R. L. Chauvin. 1992. Suppression of the Colorado potato beetle (Coleoptera: Chrysomelidae) with augmentative releases of predaceous stinkbugs (Hemiptera: Pentatomidae). J. Econ. Entomol. 85: 720-726. 
Cohen, A. C., and L. Smith. 1998. A novel concept in artificial diets for Chrysoperla ufilabris: the efficacy of solid diet. Biol. Contr. 13:49-54.

Coudron, T. A., J. L. Wittmeyer, and Y. Kim. 2002. Life history and cost analysis for continuous rearing of Podisus maculiventris (Say) (Heteroptera: Pentatomidae) on a zoophytogenous artificial diet. J. Econ. Entomol. 95: 1159-1168.

De Clercq P., and D. Degheele. 1992. A meat-based diet for rearing the predatory stink bugs Podisus maculiventris and Podisus sagitta (Heteroptera: Pentatomidae).

Entomophaga 37: 149-157.

De Clercq, P., and D. Degheele. 1997. Effects of mating status on body weight, oviposition, egg load, and predation in the predatory stinkbug Podisus maculiventris (Heteroptera: Pentatomidae). Ann. Entomol. Soc. Am. 90: 120-127.

De Clercq, P., F. Merleved, and L. Tirry. 1998. Unnatural prey and artificial diets for rearing Podisus maculiventris (Heteroptera: Pentatomidae). Biol. Contr. 12: 137-142.

Decoursey, R. M., and C. O. Esselbaugh. 1962. Descriptions of the nymphal stages of some North American Pentatomidae (Hemipera-Heteroptera). Ann. Entomol. Soc. Am. 55: $323-342$.

Desurmont, G., and P. A. Weston. 2008. Predation by Podisus maculiventris (Say) (Hemiptera: Pentatomidae) on viburnum leaf beetle, Pyrrhalta viburni (Paykull) (Coleoptera: Chrysomelidae), under laboratory and field conditions. Environ. Entomol. 37: 12411251.

Eilenberg E., A. Hajek, and C. Lomer. 2001. Suggestions for unifying the terminology in biological control. Biocontrol 46: 387-400 
Grundy P, D. Maelzer, A. Bruce, and E. Hassan. 2000. A mass rearing method for the assassin bug Pristhesancus plagipennis (Hemiptera: Reduviidae). Biol. Contr. 18: 243250.

Hough-Goldstein, J., and D. McPherson. 1996. Comparison of Perillus bioculatus and Podisus maculiventris (Hemiptera: Pentatomidae) as potential control agents of the Colorado potato beetle (Coleoptera: Chrysomelidae). J. Econ. Entomol. 89: 1116-1123.

Hutchins, S. H., L. G. Higley, and L. P. Pedigo. 1988. Injury equivalency as a basis for developing multiple-species economic injury levels. J. Econ. Entomol. 81: 1-8.

Lacerda, M. C., A. M. R. M. Ferreira, T. V. Zanucio, J. C. Zanucio, A. S. Bernardino, and M. C. Espindula. 2004. Development and reproduction of Podisus distinctus (Heteroptera: Pentatomidae) fed on larvae of Bombyx mori (Lepidoptera: Bomycidae). Brazilian J. Biol. 64: 237-242.

Marston, N. L., G. T. Schmidt, K. D. Biever, and W. A. Dickerson. 1978. Reaction of five species of soybean caterpillars to attack by the predator, Podisus maculiventris. Environ. Entomol. 7: 53-56.

McPherson, J. E. 1980. A list of the prey species of Podisus maculiventris (Hemiptera: Pentatomidae). Great Lakes Entomol. 13: 18-24.

McPherson, J.E. 1982. The Pentatomoidea (Hemiptera) of northeastern North America with emphasis on the fauna of Illinois. Southern Illinois University Press, Carbondale, IL.

Mukerji, M. K., and E. J. LeRoux. 1965. Laboratory rearing of a Quebec strain of the pentatomid predator, Podisus maculiventris (Say) (Hemiptera: Pentatomidae). Phytoprotection 46: 40-60. 
Obrycki, J. J., L. C. Lewis, and D. B. Orr. 1997. Augmentative releases of entomophagous species in annual cropping systems. Biol. Contr. 10: 30-36.

Omkar, J. Sahu, and G. Kumar. 2010. Effect of prey quantity on reproductive and developmental attributes of a ladybird beetle, Anegleis cardoni. Int. J. Trop. Insect Sci. 30: $48-56$.

Parella, M. P., K. M. Heinz, and L. Nunney. 1992. Biological control through augmentative releases of natural enemies: a strategy whose time has come. Am. Entomol. 38: 172-179.

Pedigo, L. P. 2002. Entomology and pest management, $4^{\text {th }}$ ed. Prentice Hall, Upper saddle river NJ.

Pires, E. M., J. C. Zanuncio, and J. E. Serrão. 2011. Cannibalism of Brontocoris tabidus and Podisus nigrispinus during periods of prerelease without food or fed with Eucalyptus cloeziana plants. Phytoparasitica 39: 27-34.

Reeve J. D., M. G. Rojas, and J. A. Morales-Ramos. 2003. Artificial diet and rearing methods for Thanasimus dubius (Coleoptera: Cleridae), a predator of bark beetles (Coleoptera: Scolytidae). Biol. Contr. 27: 315-322.

Riddick, E. W. 2009. Benefits and limitations of factitious prey and artificial diets on life parameters of predatory beetles, bugs, and lacewings: a mini-review. Biocontrol 54: 325339.

Ridgeway, R. L., R. K. Morrison, and M. Badgley. 1970. Mass rearing a green lacewing. J. Econ. Entomol. 63: 834-836.

SAS Institute. 2008. SAS Online Doc ${ }^{\circledR}$ version 9.1.3. SAS Institute. Cary, NC. 
Silva, R. B., J. E. Zanuncio, J. E. Serrao, E. R. Lima, M. L. C. Figueiredo, and I. Cruz. 2009. Suitability of different artificial diets for development and survival of stages of the predaceous ladybird beetle Eriopis connexa. Phytoparasitica 37: 115-123.

Strohmeyer, H. H., N. E. Stamp, C. M. Jaromski, and M. D. Bowers. 1998. Prey species and prey diet affect growth of invertebrate predators. Ecol. Entomol. 23: 68-79.

Uddin, J., N. J. Holliday, and P. A. MacKay. 2005. Rearing lacewings, Chrysoperla carnea and Chrysopa oculata (Neuroptera: Chrysopidae), on prepupae of alfalfa leafcutting bee, Megachile rotundata (Hymenoptera: Megachilidae). Proc. Entomol. Soc. Manitoba 61: 11-19.

Van Lenteren., J. C. 2006. How not to evaluate augmentative biological control. Biol. Contr. 29: 115-118.

Warren, L. O., and G. Wallis. 1971. Biology of the spined soldier bug, Podisus maculiventris (Hemiptera: Pentatomidae). J. Ga. Entomol. Soc. 6: 109-116.

Wiedenmann, R. N., and R. J. O'Neil. 1990. Effects of low rates of predation on selected lifehistory characteristics of Podisus maculiventris (Say) (Heteroptera: Pentatomidae). Can. Entomol. 122: 271-283. 
Table 1. Percentage feeding preference of $P$. maculiventris on different life stages of $T$. molitor

\begin{tabular}{|c|c|c|c|c|}
\hline $\begin{array}{c}\text { P. maculiventris } \\
\text { Stage }\end{array}$ & $\mathrm{n}$ & $\begin{array}{c}\text { Frequency of no } \\
\text { choice }\end{array}$ & $\begin{array}{l}\text { Choice to } T \text {. } \\
\text { molitor stage }\end{array}$ & $\%$ choice \\
\hline Adult & 36 & 4 & $\begin{array}{c}\text { Adult } \\
\text { Pupa } \\
\text { Large larva } \\
\text { Small larva }\end{array}$ & $\begin{array}{c}9.37 \% \mathrm{~b}^{*} \\
21.87 \% \mathrm{ab} \\
50.00 \% \mathrm{a} \\
18.75 \% \mathrm{~b}\end{array}$ \\
\hline Fifth instar & 36 & 21 & $\begin{array}{c}\text { Adult } \\
\text { Pupa } \\
\text { Large larva } \\
\text { Small larva }\end{array}$ & $\begin{array}{c}33.33 \% \mathrm{ab} \\
13.33 \% \mathrm{ab} \\
46.66 \% \mathrm{a} \\
6.66 \% \mathrm{~b}\end{array}$ \\
\hline Third instar & 36 & 23 & $\begin{array}{c}\text { Adult } \\
\text { Pupa } \\
\text { Large larva } \\
\text { Small larva }\end{array}$ & $\begin{array}{r}15.38 \% \mathrm{ab} \\
23.07 \% \mathrm{ab} \\
53.84 \% \mathrm{a} \\
7.69 \% \mathrm{~b}\end{array}$ \\
\hline
\end{tabular}

* Percentage preferences within each stage of P. maculiventris followed by the same letter are not significantly different at $P>0.05$ ( $\chi^{2}$ test). 
Table 2. Amount of hemolymph (mean \pm SEM) of $T$. molitor consumed by different stages of $\boldsymbol{P}$. maculiventris per day and feeding equivalency when the feeding amount by second instar is set as 1.00. Note that first instar is not predacious

\begin{tabular}{cccc}
\hline P. maculiventris stage & $\mathrm{n}$ & $\begin{array}{c}\text { Amount of hemolymph } \\
\text { consumed }(\mathrm{g})\end{array}$ & Feeding equivalency \\
\hline Second instar & 30 & $0.003 \pm 0.001 \mathrm{~d}^{*}$ & 1.00 \\
Third instar & 30 & $0.006 \pm 0.002 \mathrm{~d}$ & 1.83 \\
Fourth instar & 30 & $0.019 \pm 0.006 \mathrm{bc}$ & 5.13 \\
Fifth instar & 30 & $0.035 \pm 0.011 \mathrm{a}$ & 9.45 \\
Adult male & 15 & $0.023 \pm 0.010 \mathrm{ab}$ & 6.21 \\
Adult female & 15 & $0.021 \pm 0.009 \mathrm{bc}$ & 5.67 \\
\hline
\end{tabular}

* mean hemolymph consumed followed by the same letters is not significantly different $(P>$ 0.05; Tukey's HSD test). 


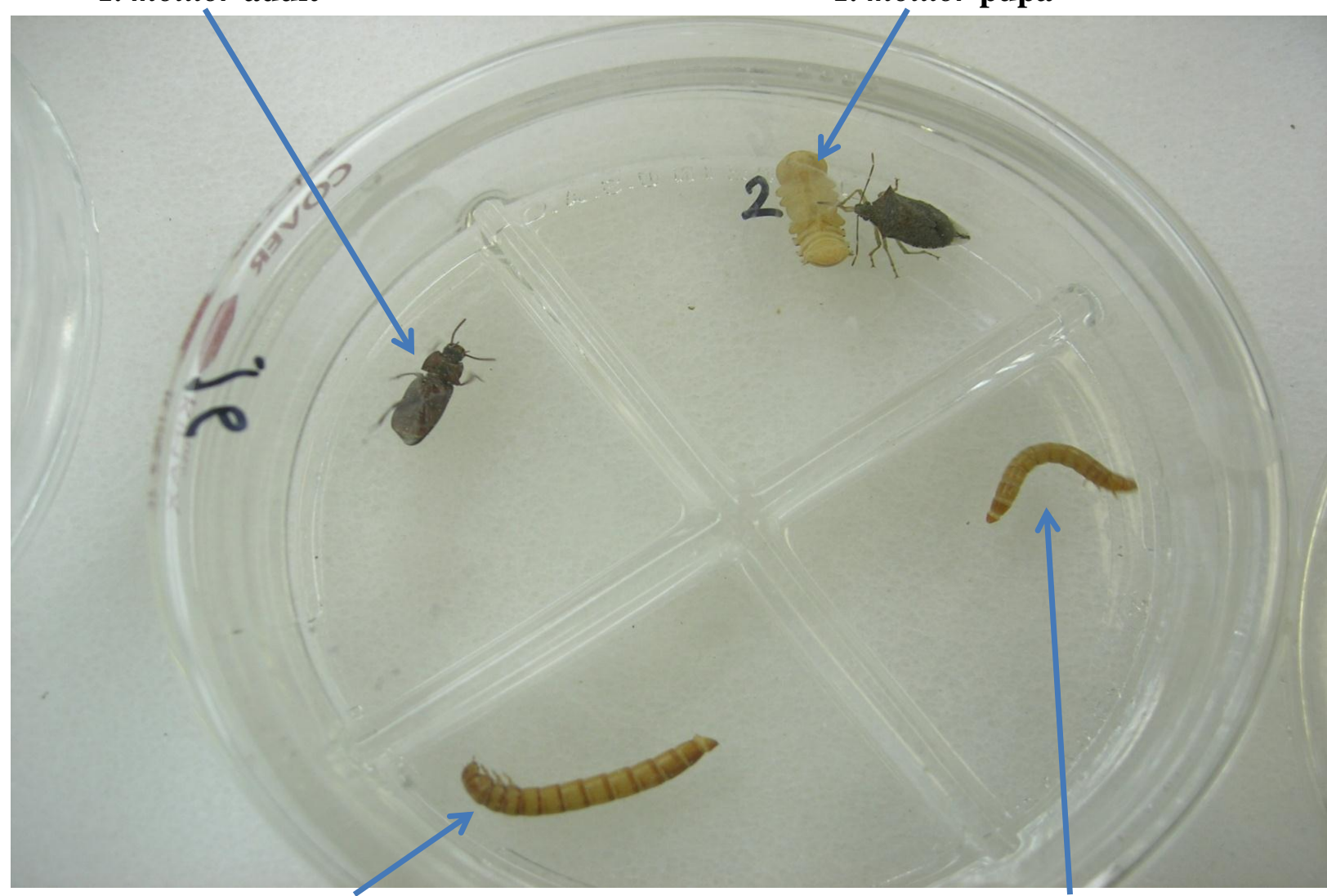

T. molitor large larva

T. molitor small larva

Fig. 1. An arena for testing preference of $P$. maculiventris on different $T$. molitor stages in a quadrant Petri dish. 


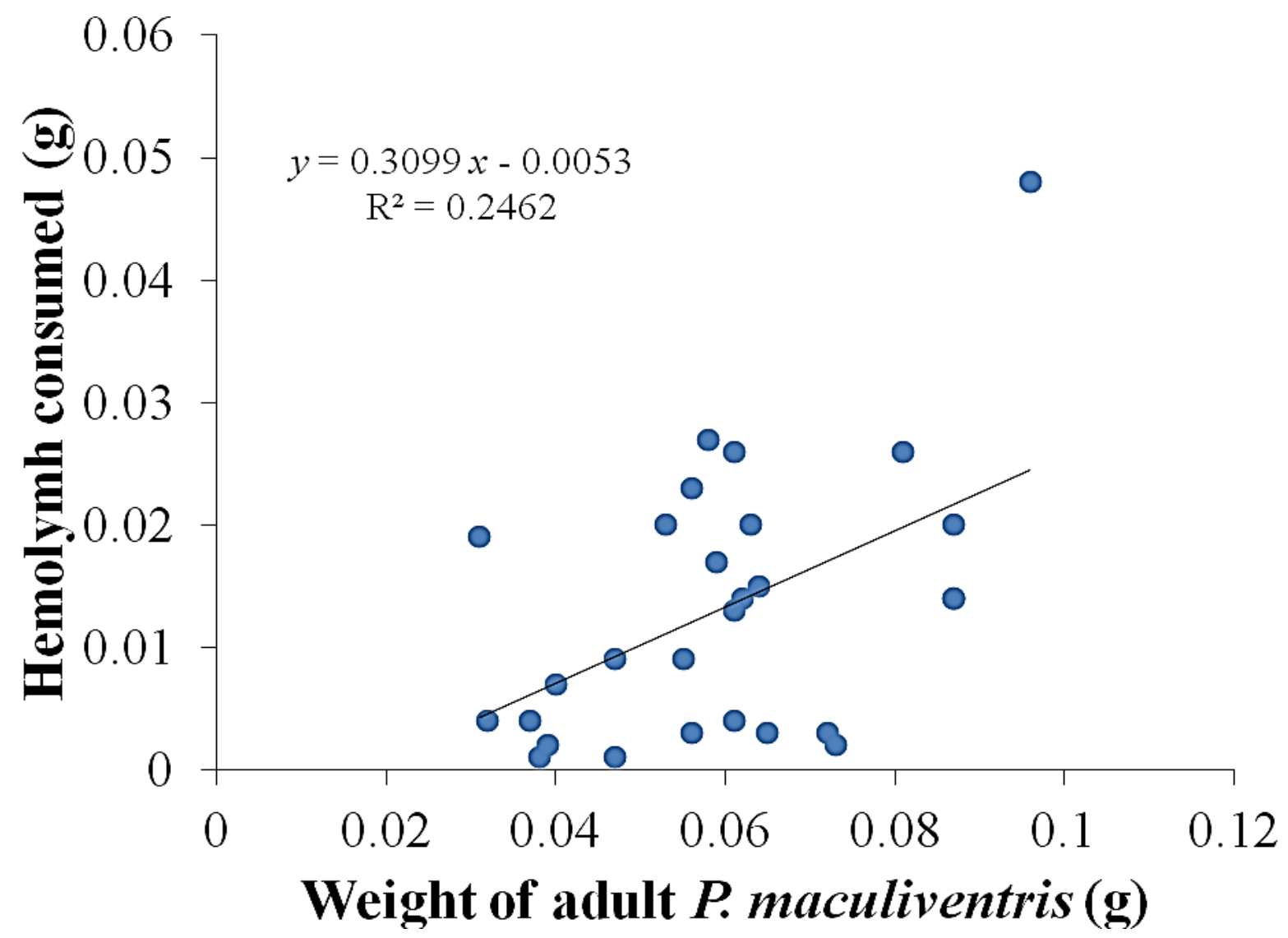

Fig. 2. Relationship between adult $P$. maculiventris body weight and amount of $T$. molitor hemolymph consumed. 


\title{
CHAPTER 3: Feeding Preference and Feeding Behavior of Podisus maculiventris on Smooth, Hairy and Coleopteran Larvae
}

\begin{abstract}
Feeding of multiple prey by generalist predators could have positive or negative effects in biological control. Determination of prey preference of a generalist predator is crucial to predict predation in a field situation. This study was conducted to investigate feeding preference, behavior and ability of a generalist predator Podisus maculiventris (Say) (Hemiptera: Pentatomidae) on various types of larvae to develop a successful augmentative biological control strategy. A series of laboratory experiments were carried out to determine feeding preference and to estimate feeding ability of $P$. maculiventris on three types of larvae (i.e. smooth, hairy, and coleopterans). The result of this experiment showed that adult $P$. maculiventris significantly $\left(\chi^{2}=\right.$ 17.64; d.f. $=2 ; P=0.0001)$ preferred to feed on smooth larvae, Evergestis rimosalis (Lepidoptera: Crambidae) compared to coleopteran larvae, Epilachna varivestis (Coleoptera: Coccinellidae) or a hairy caterpillar, Hyphantria cunea, (Lepidoptera: Arctiidae). The results of this study also showed that $P$. maculiventris caused the highest mortality to Pieris rapae (Lepidoptera: Pieridae) larvae and the least mortality to Hyphantria cunea (Lepidoptera: Arctiidae) larvae. The practical applications of the results related to using P. maculiventris for controlling various types of larvae are discussed.
\end{abstract}

Key words: choice test, alternate prey, fall webworm, biological control 
Since the first successful biological control in the United States using vedalia beetles to control cottony cushion scale in 1889 (Caltagirone and Doutt 1989), many specialist and generalist predators have been used in biological control (Bale et al. 2008). Specialist predators have a high degree of host specificity and are considered appropriate to use in biological control (Coppel and Mertins 1997). However, the long held view among biological control practitioners regarding the relative importance of specialist predators compared to generalist predators in pest control has changed (Symondson et al. 2002). Previous studies have revealed that generalist predators in certain manipulated systems could be as important as specialist predators in other systems in bringing pest population below damage level (Edwards et al. 1979, Chiverton 1985). Many generalist predators including carabids (Lövei and Sunderland 1996), coccinellids (Cottrell and Yeargan 1998), neuropterans (Jacometti et al. 2010) and hemipterans (Stoner 1970, Stoner et al. 1975) are able to feed and survive on plant material or alternative prey even when their major prey is absent (Wyss 1995, Jacometti et al. 2010). Therefore, the presence of alternative food sources in a crop field could improve biological control using omnivorous predators (Eubanks and Denno 2000 a, Gonza'lez-Ferna'ndez et al 2008). However, the presence of alternate prey or food within or near a field could negatively affect biological control because the predator may prefer the alternate food sources (Desneux and O’Neil 2008). Also, generalist predators have a certain degree of preferences to a particular type of prey (Richards 1982, Houck 1986). Dyer and Floyd (1993) conducted a study to determine host range of a generalist predator and reported that prey characteristics (e.g. host breadth, prey chemistry, prey behavior and prey morphology) played important roles for the acceptance of prey. Other studies reported that hemipteran predators exhibited prey preferences based on differences in prey mobility (Eubanks 
and Denno 2000 b), size (Cogni et al 2002), and prey species (Foglar et al. 1990, Hazzard and Ferro 1991).

The spined soldier bug, Podisus maculiventris (Say) (Hemiptera: Pentatomidae), is a generalist predator feeding on more than 70 species of insects (McPherson 1980) mostly larvae and pupae of Lepidoptera and Coleoptera (Waddill and Shepard 1975, Martson et al. 1977). P. maculiventris occurs in various agricultural ecosystems and plays a key role in the control of major insect pests including fall webworm, Hyphantria cunea; pine sawfly, Neodiprion spp.; eastern tent caterpillar, Malacosoma americanum; elm leaf beetle, Pyrrhalta luteola and Colorado potato beetle, Leptinotarsa decemlineata (Mukerji and LeRoux 1965, Warren and Wallis 1971, McPherson 1980). P. maculiventris is a noticeable predator of field crop pests (Waddill and Shepard 1975) and has high potential to control many noctuid larvae and Colorado potato beetle larvae for augmentative control because of higher reproduction rate making its mass production easier (Stamopoulos and Chloridis 1994, Hough-Goldstein and McPherson 1996). Although, P. maculiventris is a generalist predator, it prefers to feed on larvae with lower defense (Martson et al. 1978). However, no study has reported feeding preference of $P$. maculiventris on larvae of different morphology.

The knowledge of prey preferences is important to determine the types of pest that can be controlled effectively by $P$. maculiventris and the effect of alternate prey upon biological control in the field. This study was carried out to investigate the potential of P. maculiventris as a generalist predator for biological control. The objectives of this study were to determine feeding preference of $P$. maculiventris on various types of larvae and to estimate the feeding ability of $P$. maculiventris on different species of three different types of larvae. 


\section{Materials and Methods}

This experiment was conducted at constant temperature $\left(21.5 \pm 1.3^{\circ} \mathrm{C}\right)$, relative humidity $(62 \pm 5 \%)$ and 15:9 (L:D) photoperiod in the entomology laboratory at West Virginia University, Morgantown, WV.

Experimental insects. All P. maculiventris used in the experiment were obtained from the colonies that have been maintained in the entomology laboratory at West Virginia University since June 2009 by feeding Tenebrio molitor (Coleoptera: Tenebrionidae). A total of five different larvae were used: fall web worm, Hyphantria cunea (Lepidoptera: Arctiidae); cabbage worm, Pieris rapae (Lepidoptera: Pieridae); cross-striped cabbage worm, Evergestis rimosalis (Lepidoptera: Crambidae); Mexican bean beetle, Epilachna varisvestis (Coleoptera:

Coccinellidae) and Colorado potato beetle, Leptinotarsa decemlineata (Coleoptera:

Chrysomelidae). These larvae were collected respectively from black cherry (Prunus serotina), cabbage (Brassica oleracea var. capitata), kale (Brassica oleracea var. acephala), soybean (Glycine max) and potato (Solanum tuberosum) from fields located in Jane Lew (Lewis County), Morgantown (Monongalia County), and Moorefield (Hardy County) in WV. The larvae were categorized into three groups: hairy larvae, smooth larvae and coleopteran larvae. The larvae were maintained in the laboratory on the leaves of respective plant until the experiment was carried out.

Feeding preference of $\boldsymbol{P}$. maculiventris: An experiment was carried out to determine the feeding preference of $P$. maculiventris on different types of larvae. One $H$. cunea, hairy larva (1.8-2.5-cm long), one E. rimosalis, smooth larva (1.9-2.4-cm long) and one E. varivestis, coleopteran larva (0.6-1.1-cm long), was randomly assigned to a quadrant Petri dish (9-cm 
diameter) (Pyrex Petri Dishes, Science Kit and Boreal Laboratories, Tonawanda, NY) (Fig. 1). Then, one $P$. maculiventris (third instar, fifth instar or adult) was introduced to the remaining quadrant of Petri dish. The experiment was repeated 20-22 times (no insect was used more than 1 time). All P. maculiventris used in this study were starved for $24 \mathrm{hr}$ before the experiment. To collect data more precisely, the feeding preference of $P$. maculiventris was videotaped for $24 \mathrm{hr}$ using infrared cameras (The Hawk Eye Nature Cam, West Linn, OR) and a 4-channel DVR (Falco Model LX-4PRO, Falco Pro Series, Taiwan). From the video, the types of larvae that $P$. maculiventris "first attacked" and ultimately "fed on" were recorded. The two preference frequency data were analyzed using chi-square test (PROC FREQ, SAS Institute 2008) to determine the feeding preference of $P$. maculiventris.

Feeding ability of $\boldsymbol{P}$. maculiventris: An experiment was conducted to test feeding ability of $P$. maculiventris on two species of the smooth larvae ( $P$. rapae [1.9-2.4-cm long] and $E$. rimosalis [1.7-2.4-cm long]), two species of the coleopteran larvae (E. varivestis [0.6-0.8-cm long] and L. decemlineata [0.8-1.2-cm length]) and one species of hairy larva; H. cunea (1.92.5-cm long). Each of the species was put in a plastic Petri dish (5.5-cm diameter) (Lab-Tech Plastic Petri Dish, Miles Laboratories Inc., Naperville, IL) and then, one P. maculiventris (third instar, fifth instar, or adult) was introduced into Petri dish. The experiment was videotaped for 24 hr using infrared cameras and a- 4 channel DVR for the 24 hour period. This experiment was repeated 12 times (no insect was used $>1$ time). Numbers of each larval type that was killed by P. maculiventris feeding in $24 \mathrm{hr}$ was recorded. The data was analyzed with ANOVA and the mean number of attacks required prior to effective feeding by $P$. maculiventris for various larval types were compared with Tukey's HSD test at $0.05 \%$ error rate (PROC GLM, SAS Institute 2008). 


\section{Results}

Feeding preference of $P$. maculiventris: Overall, adult $P$. maculiventris significantly $\left(\chi^{2}\right.$ $=13.30 ;$ d.f. $=2 ; P=0.001)$ preferred to first attack a smooth larva (Table 1$)$. The pair-wise comparison for the first attack also showed a similar result. Adult P. maculiventris significantly preferred smooth larvae over coleopteran $\left(\chi^{2}=4.26\right.$; d.f. $\left.=1 ; P<0.05\right)$ or hairy larvae $\left(\chi^{2}=\right.$ 11.60; d.f. $=1 ; P=0.0008)$. Adult $P$. maculiventris also showed significant preference to make first attack to coleopteran larvae over hairy larvae $\left(\chi^{2}=2.66\right.$; d.f. $\left.=1 ; P<0.05\right)$. The fifth instar P. maculiventris showed a significant $\left(\chi^{2}=6.63 ;\right.$ d.f $\left.=2 ; \mathrm{P}<0.05\right)$ preference to first attack for smooth larvae. Pair-wise comparisons indicated that the fifth instar P. maculiventris significantly preferred smooth larvae over coleopteran $\left(\chi^{2}=4.75\right.$; d.f. $\left.=1 ; P<0.05\right)$ or hairy larvae $\left(\chi^{2}=4.75\right.$; d.f. $=1 ; P<0.05)$. However, the fifth instar $P$. maculiventris did not show significant difference in preference between coleopteran and hairy larvae $\left(\chi^{2}=0\right.$; d.f. $\left.=1 ; P>0.05\right)$. The third instar $P$. maculiventris showed a significant $\left(\chi^{2}=9.33\right.$; d.f. $\left.=2 ; \mathrm{P}<0.05\right)$ preference to make first attack for smooth larvae. Pair-wise comparisons showed that the third instar P. maculiventris had significant preference to first attack $\left(\chi^{2}=0.8\right.$; d.f. $\left.=1 ; P<0.05\right)$ for smooth larvae over coleopteran and significant preference to make first attack $\left(\chi^{2}=7.00 ;\right.$ d.f. $\left.=1 ; P<0.05\right)$ for smooth larvae over hairy larvae. The third instar did not show significant $(P>0.05)$ difference in preference to make first attack between coleopteran and hairy larvae.

The results of feeding preference test showed that adult $P$. maculiventris significantly $\left(\chi^{2}\right.$ $=17.66$; d.f. $=2 ; P=0.0001)$ preferred to feed upon smooth larvae (Table 2). Pair-wise comparisons showed that adult $P$. maculiventris significantly preferred smooth larvae over coleopteran $\left(\chi^{2}=4.48\right.$; d.f. $\left.=1 ; P<0.05\right)$ or hairy larvae $\left(\chi^{2}=16.20 ;\right.$ d.f. $\left.=1 ; P=0.0001\right)$. Adult P. maculiventris also showed significant feeding preference to coleopteran larvae over hairy 
larvae $\left(\chi^{2}=5.44 ;\right.$ d.f. $\left.=1 ; P<0.019\right)$. The fifth instar $P$. maculiventris showed a significant $\left(\chi^{2}=\right.$ 20.8 ; d.f. $=2 ; P<0.05)$ feeding preference on smooth larvae over hairy and coleopteran larvae. Pair-wise comparisons showed that the fifth instar $P$. maculiventris significantly preferred smooth larvae over coleopteran $\left(\chi^{2}=7.2 ;\right.$ d.f. $\left.=1 ; P<0.05\right)$ or hairy larvae $\left(\chi^{2}=16.00 ;\right.$ d.f $=1 ; P$ $<0.05)$. The fifth instar P. maculiventris also significantly prefer to feed on coleopteran larvae over hairy larvae $\left(\chi^{2}=4.00 ;\right.$ d.f. $\left.=1 ; P<0.05\right)$. The third instar $P$. maculiventris showed a significant $\left(\chi^{2}=6.72 ;\right.$ d.f. $\left.=2 ; \mathrm{P}<0.05\right)$ preference for feeding on smooth larvae. Pair-wise comparisons indicated that the third instar $P$. maculiventris did not show significant preference for smooth larvae over coleopteran larvae $\left(\chi^{2}=0.8\right.$; d.f. $\left.=1 ; P<0.05\right)$; however it showed significant feeding preferences for smooth larvae over hairy larvae $\left(\chi^{2}=7.00 ;\right.$ d.f. $\left.=1 ; P<0.05\right)$ and for coleopteran over hairy larvae $\left(\chi^{2}=4.00 ;\right.$ d.f. $\left.=1 ; P<0.05\right)$.

Feeding ability of $P$. maculiventris: The result of this experiment showed that $P$. maculiventris caused highest mortality to $P$. rapae larvae (Fig. 2). $P$. maculiventris third instars caused highest percentage mortality to $P$. rapae and $E$. rimosalis larvae. For fifth instar $P$. maculiventris, the mortality was highest for E. rimosalis followed by $P$. rapae and $L$. decemlineata larvae. The adult $P$. maculiventris caused highest mortality to $P$. rapae and $E$. rimosalis followed by $L$. decimlineata. The number of attacks required prior to effective feeding upon different larval species differed significantly for the third instar $P$. maculiventris ( $F=8.05$; d.f. $=4,27 ; P<0.001)$. The third instars needed six attacks to effectively feed on $H$. cunea and E. varivestis larvae (Fig. 3). However, there was no effect of larvae species on the number of attacks required prior to effective feeding for the fifth instar $(F=1.88$; d.f. $=4,27 ; P>0.05)$ or adult $P$. maculiventris $(F=1.70$; d.f. $=4,38 ; P>0.05)$. 


\section{Discussion}

Possessing hairs or spines on the body is one of the major defense mechanisms against predation for many larvae (Dyer 1997, Murphy et al. 2010). Our study showed that $P$. maculiventris significantly preferred to feed on smooth larvae over coleopteran and hairy larvae because the hairy and coleopteran larvae used in this study had long hairs and spines. $P$. maculiventris also showed significant preference for feeding on coleopteran larvae compared to hairy larvae. These results are congruent with those of Dyer (1997) who reported that hairy larvae highly deterred another hemipteran predator Apiomerus pictipes (Hemiptera: Reduviidae). Hemipteran predators have mouthparts that pierce through the integument of the prey and suck their hemolymph. The presence of hair or spines on the body of prey could make $P$. maculiventris difficult to find a site on prey's body to attack, resulting in less preference for these types of larvae.

We also found that $P$. maculiventris showed the highest feeding ability to smooth larvae followed by coleopteran larvae and hairy larva. This indicated that smooth larvae very were vulnerable to $P$. maculiventris attack. We also found that the fifth instars and adults of $P$. maculiventris were able to feed on relatively higher numbers of E. varivestis larvae. It is possible that $P$. maculiventris were able to feed on hairy or spiny larvae if the hairs or spines of prey were shorter than the mouthparts of $P$. maculiventris. The length of the mouthparts of $P$. maculiventris increases with the instars (i.e. 3-4-mm, 4-5-mm and 5-6-mm for the third instar, fifth instar and adult, respectively). The lengths of E. varivestis spines were relatively short which might have enabled the fifth instars and adult $P$. maculiventris to effectively feed upon it. The hairs of $H$. cunea, however, were very long and adult $P$. maculiventris could not feed them. Only the fifth 
instar $P$. maculiventris were able to feed on relatively higher numbers of hairy larvae because the fifth instars are more aggressive and voracious than any other stages of $P$. maculiventris.

P. maculiventris occurs in many agricultural fields including soybean and potato (McPherson et al. 1982, Heimpel et al. 1992). In an agriculture field such as soybean, $P$. maculiventris can feed on many species of pests (McPherson 1980) including many smooth (Martson et al. 1978) and coleopteran larvae. Our study indicated that $P$. maculiventris will most likely be an effective biological control agent against smooth larvae, such as soybean looper, Trichoplusia ni compared to the Mexican bean beetle, Epilachna varivestis larvae in soybean. Although P. maculiventris feed on many hairy larval species such as H. cunea and Malacosoma americanum (Lepidoptera: Lasiocampidae) (Morris 1963, Evans 1983), our study indicated that P. maculiventris may not be an effective biological control agent against hairy larvae.

The results of this study have two important considerations for using $P$. maculiventris in biological control. First, P. maculiventris may be considered for biological control against smooth larvae because $P$. maculiventris preferred and effectively control smooth larvae. Second, the type of alternate prey present in the field should also be considered when using $P$. maculiventris in augmentative release. Alternate prey could affect the biological control negatively if they are preferred species for the natural enemy. Our study showed that $P$. maculiventris fed upon fewer numbers hairy larvae when smooth larvae were present, and thus P. maculiventris should not be released to control less preferred larvae when alternate prey such as smooth larvae are present.

\section{Acknowledgements}

We thank Vicki Kondo, Matthew McKinney, Vimal Verghese and Sunghoon Baek for their helps with collecting various larvae and rearing of the P. maculiventris for this research. 
Thanks are also due to Sam Harper, Moorefield, WV for permitting us to collect larvae from his field. The project was supported by State Horticultural Association of Pennsylvania and Hatch Project at West Virginia University.

\section{References cited}

Bale, J. S., J. C. van Lenteren, and F. Bigler. 2008. Biological control and sustainable food production. Philos. Trans. R. Soc. B. 363: 761-776.

Caltagirone, L. E., and R. L. Doutt. 1989. The history of the Vedalia beetle importation to California and its impact on the development of biological control. Annu. Rev. Entomol. 34: $1-16$.

Chiverton, P. A., 1986. Predator density manipulation and its effect on populations of Rhopalosiphum padi (Hom.: Aphididae) in spring barley. Ann. Appl. Biol. 109: 49-60.

Cogni, R., A. V. L. Freitas, and F. Amaral Filho. 2002. Influence of prey size on predation success by Zelus longipes L. (Het., Reduviidae). J. Appl. Entomol. 126: 74-78.

Cottrell, T. E., and K. V. Yeargan. 1998. Effect of pollen on Coleomegilla maculata (Coleoptera: Coccinellidae) population density, predation, and cannibalism in sweet corn. Environ. Entomol. 27: 1402-1410.

Coppel, H. C., and J. W. Mertins. 1977. Biological insect pest suppression. Springer-Verlag, Berlin, Germany.

Desneux, N., and R. J. O'Neil. 2008. Potential of an alternative prey to disrupt predation of the generalist predator, Orius insidiosus, on the pest aphid, Aphis glycines, via short-term indirect interactions. Bull. Entomol. Res. 98: 631-39.

Dyer, L. A. 1997. Effectiveness of caterpillar defenses against three species of invertebrate predators. J. Res. Lepidopt. 34: 48-68. 
Dyer, L. A., and T. Floyd. 1993. Determinants of predation on phytophagous insects: the importance of diet breadth. Oecologia 96: 575-582.

Edwards, C. A., K. D. Sunderaland, and K. S. Gerorge. 1979. Studies on polyphagous predators of cereal aphids. J. Appl. Ecol. 16: 811-823.

Eubanks, M. D., and R. F. Denno. 2000 a. Host plants mediate omnivore-herbivore interactions and influence prey suppression. Ecology 81: 936-947.

Eubanks, M. D., and R. F. Denno. 2000 b. Health food versus fast food: the effects of prey quality and mobility on prey selection by a generalist predator and indirect interactions among prey species. Ecol. Entomol. 25: 140-146.

Evans, E. W. 1983. Niche relations of predatory stinkbugs (Podisus spp., Pentatomidae) attacking tent caterpillars (Malacosoma americanum, Lasiocampidae). Am. Midl. Nat.109: 316-323.

Foglar, H., J. C. Malausa, and E. Wajnberg. 1990. The functional response and preference of Macrolophus caliginosus (Heteroptera: Miridae) for two of its prey: Myzus persicae and Tetranychus urticae. Entomophaga 35: 465-474.

Gonza'lez-Ferna’́ndez J. J., F. de la Peña, J. I. Hormaza, J. R. Boyero, J. M. Vela, E. Wong, M. M. Trigo, and M. Montserrat. 2009. Alternative food improves the combined effect of an omnivore and a predator on biological pest control. A case study in avocado orchards. Bull. Entomol. Res. 99: 433-444.

Hazzard, R. V., and D. N. Ferro. 1991. Feeding responses of adult Coleomegilla maculata (Coleoptera: Coccinellidae) to eggs of Colorado potato beetle (Coleoptera: Chrysomelidae) and green peach aphids (Homoptera: Aphididae). Environ. Entomol. 20: 644-651. 
Heimpel, G. E., and J. A. Hough-Goldstein. 1992. A survey of arthropod predators of Leptinotarsa decemlineata (Say) in Delaware potato fields. J. Agric. Entomol. 9: 37142.

Houck, M. A. 1986. Prey preference in Stethorus punctum (Coleoptera: Coccinellidae). Environ. Entomol. 15: 967-970.

Hough-Goldstein, J. A., and D. McPherson. 1996. Comparison of Perillus bioculatus and Podisus maculiventris (Hemiptera: Pentatomidae) as potential control agents of the Colorado potato beetle (Coleoptera: Chrysomelidae). J. Econ. Entomol. 89: 1116-1123.

Jacometti, M., N. Jrgensen, and S. Wratten. 2010. Enhancing biological control by an omnivorous by an omnivorous lacewing: floral resources reduce aphid numbers at low aphid densities. Biol. Contr. 55: 159-165.

Lövei, G. L., and K. D. Sunderland. 1996. Ecology and behavior of ground beetles (Coleoptera: Carabidae). Annu. Rev. Entomol. 41: 231-256.

Marston, N. L., G. T. Schmidt, K. D. Biever, and W. A. Dickerson. 1978. Reaction of five species of soybean caterpillars to attack by the predator Podisus maculiventris. Environ. Entomol. 7: 53-56.

McPherson, J. E. 1980. A list of the prey species of Podisus maculiventris (Hemiptera: Pentatomidae). Great Lakes Entomol. 13: 18-24.

McPherson, R. M., J. C. Smith, and W. A. Allen. 1982. Incidence of arthropod predators in different soybean cropping systems. Environ. Entomol. 11: 685-689.

Morris, R. F. 1963. The effect of predator age and prey defense on the functional response of Podisus maculiventris Say to the density of Hyphantria cunea Drury. Can. Entomol. 95: 1009-1020. 
Mukerji, M. K., and E. J. LeRoux. 1965. Laboratory rearing of a Quebec strain of the pentatomid predator, Podisus maculiventris (Say) (Hemiptera: Pentatomidae). Phytoprotection 46: 40-60.

Murphy, S. M., S. M. Leahy, L. S. Williams, and J. T. Lill. 2010. Stinging spines protect slug caterpillars (Limacodidae) from multiple generalist predators. Behav. Ecol. 21: 153-160.

Richards, L. J. 1982. Prey selection by an intertidal beetle: field test of an optimal diet model. Oecologia 55: 325-332.

SAS Institute. 2008. SAS OnlineDoc® version 9.1.3. SAS Institute. Cary, NC.

Stampoulos D. C., and A. Chloridis. 1994. Predation rates, survivorship and development of Podisus maculiventris (Het.: Pentatomidae) on larvae of Leptinotarsa decemlineata (Col.: Chrysomelidae) and Pieris brassicae (Lep.: Pieridae), under field conditions. Entomophaga 39: 3-9.

Stoner, A. 1970. Plant feeding by a predaceous insect. Geocoris punctipes. J. Econ. Entomol. 63: 1911-1915.

Stoner, A., A. M. Metcalfe, and R. E. Weeks. 1975. Plant feeding by Reduviidae, a predacious family (Hemiptera). J. Kansas Entomol. Soc. 48: 185-188.

Symondson, W. O. C., K. D. Sunderland, and M. H. Greenstone. 2002. Can generalist predators be effective biocontrol agents? Annu. Rev. Entomol. 47: 561-594.

Waddill, V., and M. Shephard. 1975. Dispersal of Podisus maculiventris nymphs in soybeans. Environ. Entomol. 4: 233-234.

Warren, L. O., and G. Wallis. 1971. Biology of the spined soldier bug, Podisus maculiventris (Hemiptera: Pentatomidae). J. Ga. Entomol. Soc. 6: 109-116. 
Wyss, E. 1995. The effects of weed strips on aphids and aphidophagous predators in an apple orchard. Entomol. Exp. Appl. 75: 43. 
Table 1. Frequency of first attack of $P$. maculiventris on different types of larvae

\begin{tabular}{|c|c|c|c|c|}
\hline $\begin{array}{c}\text { P. maculiventris } \\
\text { Stage }\end{array}$ & $\mathrm{n}$ & Number of no choice & $\begin{array}{c}\text { Choice to larval } \\
\text { type }\end{array}$ & $\begin{array}{l}\text { Percentage } \\
\text { preference }\end{array}$ \\
\hline Adult & 20 & 0 & $\begin{array}{c}\text { smooth } \\
\text { coleopteran } \\
\text { hairy }\end{array}$ & $\begin{array}{c}70 \% \mathrm{a}^{*} \\
25 \% \mathrm{~b} \\
5 \% \mathrm{c}\end{array}$ \\
\hline Fifth instars & 22 & 0 & $\begin{array}{c}\text { smooth } \\
\text { coleopteran } \\
\text { hairy }\end{array}$ & $\begin{array}{c}45.45 \% \text { a } \\
18.18 \% \text { b } \\
22.72 \% \text { bc }\end{array}$ \\
\hline Third instars & 22 & 0 & $\begin{array}{c}\text { smooth } \\
\text { coleopteran } \\
\text { hairy }\end{array}$ & $\begin{array}{c}54.54 \% \text { a } \\
13.63 \% \text { b } \\
22.72 \% \text { bc }\end{array}$ \\
\hline
\end{tabular}

* Percentage preferences within each stage of $P$. maculiventris followed by the same letter are not significantly different at $P>0.05\left(\chi^{2}\right.$ test $)$. 
Table 2. Feeding preference of $P$. maculiventris on different types of larvae. Note that adult P. maculiventris might feed on $>1$ type of larvae

\begin{tabular}{ccccc}
\hline $\begin{array}{c}P . \text { maculiventris } \\
\text { Stage }\end{array}$ & $\mathrm{n}$ & Number of no choice & $\begin{array}{c}\text { Choice to larva } \\
\text { type }\end{array}$ & $\begin{array}{c}\text { Percentage } \\
\text { preference }\end{array}$ \\
\hline Adult & 20 & 0 & $\begin{array}{c}\text { smooth } \\
\text { coleopteran } \\
\text { hairy }\end{array}$ & $\begin{array}{c}95 \% \mathrm{a}^{*} \\
40 \% \mathrm{~b} \\
5 \% \mathrm{c}\end{array}$ \\
& & & smooth & $72.72 \% \mathrm{a}$ \\
& & & coleopteran & $18.18 \% \mathrm{~b}$ \\
& 22 & hairy & $0 \% \mathrm{c}$ \\
& & & smooth & $31.81 \% \mathrm{a}$ \\
& & & coleopteran & $18.18 \% \mathrm{ab}$ \\
& 22 & 11 & hairy & $0 \% \mathrm{c}$ \\
\hline
\end{tabular}

* Percentage preferences within each stage of $P$. maculiventris followed by the same letter are not significantly different at $P>0.05\left(\chi^{2}\right.$ test $)$. 


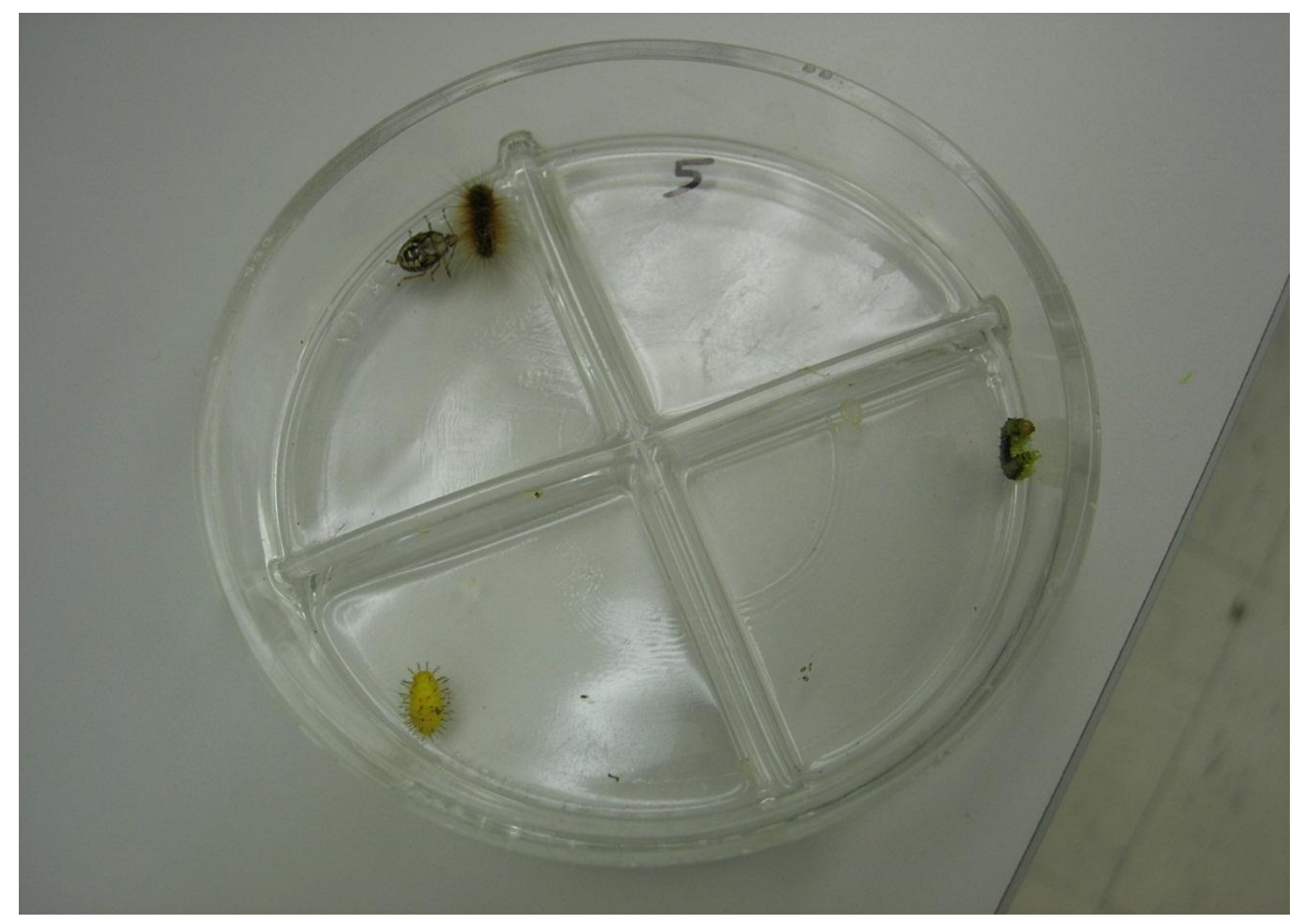

Fig. 1. An arena for testing preference of $P$. maculiventris for different types of larvae. 


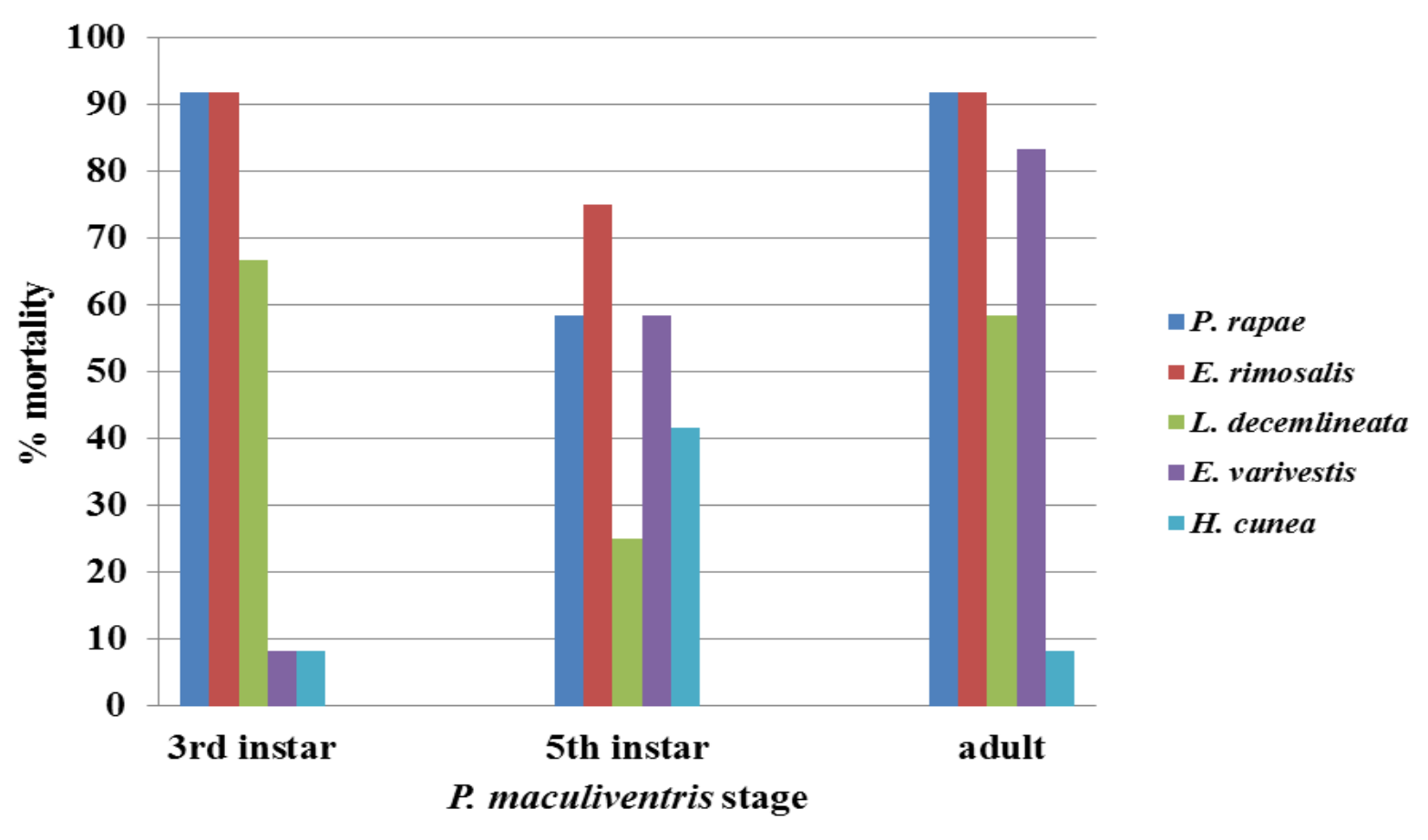

Fig. 2. Mortality of different larval species for the third instar, fifth instar, and adult P. maculiventris feeding: $P$. rapae, E. rimosalis (smooth); L. decemlineata, E. varivestis (coleopteran); H. cunea (hairy). 


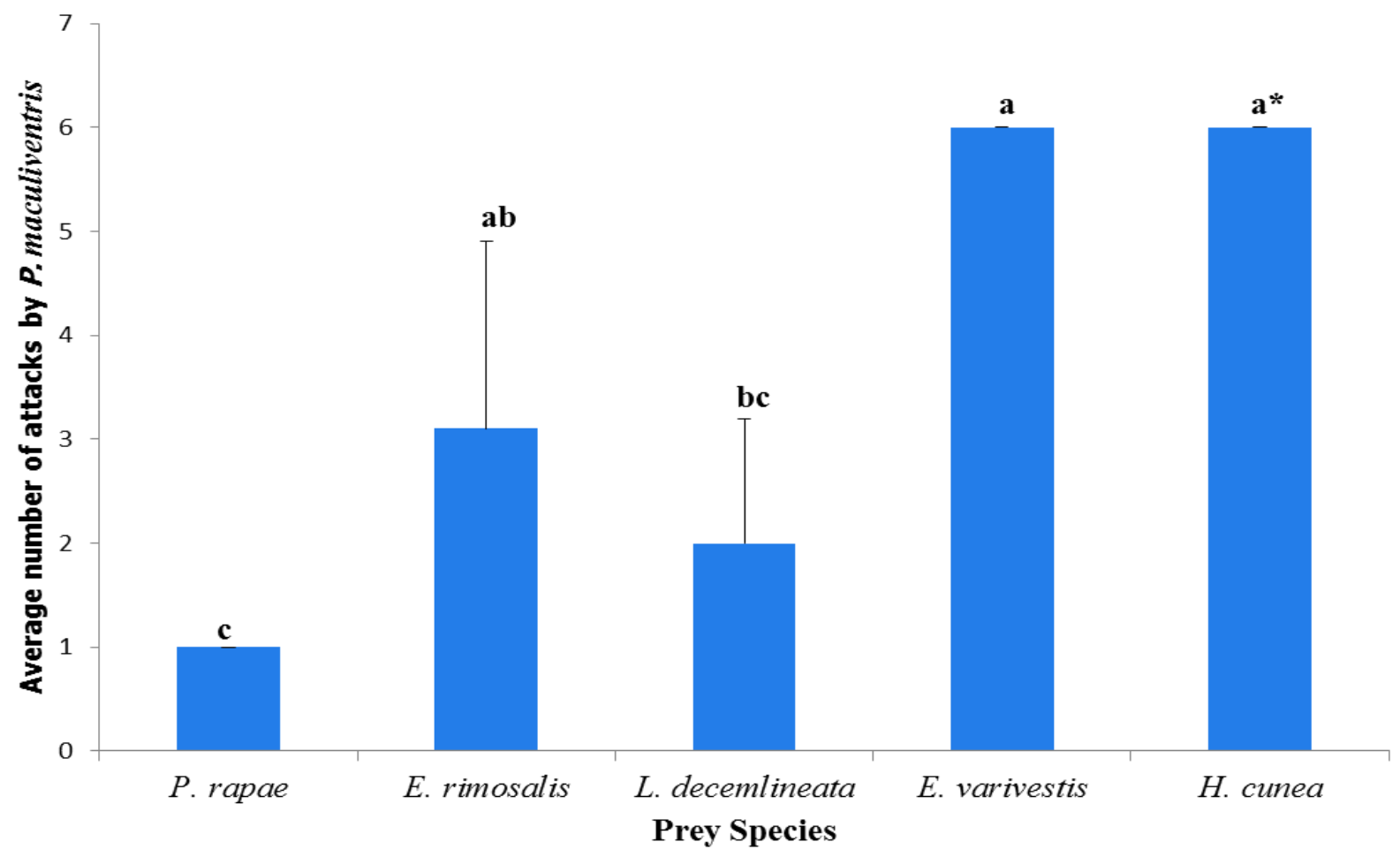

Fig. 3. Number of attacks prior to effective feeding by the third instars of $P$. maculiventris on different larvae: $P$. rapae, E. rimosalis (smooth); L. decemlineata, $E$ varivestis (coleopteran); H. cunea (hairy). Note that there was no effect of larva species on number of attack prior to effective feeding on different larvae for the fifth instar and adult $\boldsymbol{P}$. maculiventris. * means within each variable in each column followed by the same letter are not significantly different $(P>0.05$; Tukey's HSD test). 


\section{CHAPTER 4: CONCLUSION}

The spined soldier bug, Podisus maculiventris (Say) (Hemiptera: Pentatomidae), feeds on various life stages and species of insect pests (McPherson 1980). Although previous studies (Ables and McCommas 1982, Hough-Goldstein and McPherson 1996) showed that $P$. maculiventris has potential to control diverse species of insects, successful mass rearing techniques and types of the pest species that could be effectively controlled are little known. In addition, knowledge about feeding behavior of $P$. maculiventris on different life stages and species of prey is important for developing successful mass rearing and effective biological control using $P$. maculiventris.

The result of this study (Chapter 2) indicates two important implications for mass rearing of $P$. maculiventris. First, life stages of the prey should be considered while providing diet for $P$ maculiventris for mass rearing. P. maculiventris adults prefer to feed on large larva of yellow mealworm, Tenebrio molitor (Coleoptera: Tenebrionidae) over small larva or adults of $T$. molitor. Large larvae of T. molitor may be a suitable life stage of prey that could be provided in the mass rearing of $P$. maculiventris. Second, the life stages of $P$. maculiventris should also be considered for providing prey in the mass rearing system. The feeding equivalency of different stages of $P$. maculiventris could help with decision on the amount of prey to provide in the mass rearing system.

This study (Chapter 3) also revealed implications for using P. maculiventris in biological control against different types of insect pests. Morphology of the prey is an important factor for P. maculiventris. This study suggests that if there are morphologically different types of larvae in the field, $P$. maculiventris will most likely feed on smooth lepidopteran larvae. 
Further studies need to be directed to field research because various plant-associated factors and prey-plant interactions could influence the preference of $P$. maculiventris under field conditions.

\section{References Cited}

Ables, J. R., and D. W. McCommas, Jr. 1982. Efficacy of Podisus maculiventris as a predator of Ascogaster quadridentata on greenhouse cotton. J. Ga. Entomol. Soc. 17: 204-206.

Hough-Goldstein, J. A., and D. McPherson. 1996. Comparison of Perillus bioculatus and

Podisus maculiventris (Hemiptera: Pentatomidae) as potential control agents of the Colorado potato beetle (Coleoptera: Chrysomelidae). J. Econ. Entomol. 89: 1116-1123.

McPherson, J. E. 1980. A list of the prey species of Podisus maculiventris (Hemiptera:

Pentatomidae). Great Lakes Entomol. 13: 18-24. 